Marquette University

e-Publications@Marquette

$1-1-2009$

\title{
Gender and Violence in Focus: A Background for Gender Justice in Reparations
}

Margaret Urban Walker

Marquette University, margaret.walker@marquette.edu

Published version. "Gender and Violence in Focus: A Background for Gender Justice in Reparations," in The Gender of Reparations: Unsettling Sexual Hierarchies while Redressing Human Rights Violations. Eds. Ruth Rubio-Marin. Cambridge University Press, 2009: 1-17. DOI. (C 2009 Cambridge University Press. Used with permission.

Margaret Urban Walker was affiliated with Arizona State University at the time of publication. 
against women on the agenda, and into the indictments, of the tribunal. 3 In other recent conflicts on the African continent, widespread abduction, rape, sexual enslavement, and captivity of young women has been publicized, but it is unclear how, whether, and where this violence will be addressed.

\section{Gender and Violence in Focus: A Background} for Gender Justice in Reparations

\author{
Margaret Urban Walker
}

The ad hoc International Criminal Tribunal for the former Yugoslavia (ICTY), the International Criminal Tribunal for Rwanda (ICTR), and the International Criminal Court (ICC) have put sexual violence against women in contexts of conflict squarely on the map of international criminal law in the past decade. ${ }^{1}$ Acts of sexual violence can now be charged as genocide, crimes against humanity, war crimes, and grave breaches of humanitarian standards. The 1994 genocide in Rwanda produced significant coverage of mass rapes that accompanied mass killings. The 1998 Akayesu judgment of the ICTR made the historically unprecedented connection between rape and genocide, and the statute and indictments of the ICTR incorporate rape as a crime against humanity. Yet a 2004 Human Rights Watch report reveals that neither the ICTR, local courts, nor the recently launched traditional gacaca hearings are dealing adequately with sexual violence. ${ }^{2}$ The indictment and conviction of Bosnian Serb soldiers for sexual assaults and enslavement of women in Foca at the ICTY in 2001 was seen as a historic moment for the recognition of specifically sexual violence against women in the context of armed conflict. Even so, tribunal judges lamented the difficulty of getting sexual violènce

${ }^{1}$ A detailed comparative summary of convergences and differences in the statutes and actions of the ICTY, ICTR, and ICC is provided by Angela M. Banks, "Sexual Violence and International Criminal Law: An Analysis of the Ad Hoc Tribunal's Jurisprudence and the International Criminal Court's Elements of Crimes," Women's Initiatives for Gender Justice, September 2005 http://www iccwomen org/publications/resources/index.php, accessed February 26, 2009. See also Kelly D. Askin and Dorean M. Koenig, eds., Women and International Human Rights Law (Ardsley, NY: Transnational, 1999).

"Human Rights Watch, "Rape Survivors Find No Justice," http://hrw.org/english/docs/2004/ og/3o/rwanda9391.htm, accessed February 26, 2009. See also Human Rights Watch on the lack of a consistent and comprehensive approach to rape at the ICTR in "We'll Kill You You Cry: Sexual Violence in the Sierra Leone Conflict," Human Rights Watch Report 15, no. 1 (January 2003): 59 .
Despite deliberate attention to women's situations and activism by women's organizations in South Africa, the South African Truth and Reconciliation Commission (TRC) did not much succeed in inducing women, including politically active women, to talk about experiencing sexual violence. Women gave testimony to affirm grave crimes against their husbands and children, but not often those against themselves. ${ }^{4}$

Sexual violence is not, however, the only violence women suffer in situations of armed conflict and political repression. ${ }^{5}$ Rape and abusive sexual treatment are grave criminal acts, among the grossest violations of human rights and crimes against humanity when systemic in nature. Women's vulnerability to sexual violation, however, is but one of the threats and dangers women face as combatants and civilians in armed conflict or as citizens or political activists under repression. Women too are killed, wounded, tortured, mutilated, disabled, terrorized, forced to relocate or emigrate, and stranded in refugee camps. Women too lose homes, land, possessions, sources of income, local networks of material and emotional support, and family members or whole families. In some cases women's losses are the results of sexual violation;

3 See interviews with Gabrielle Kirk McDonald, then president of the ICTY, and with Elizabether Odio Benito, then justice of the ICTY, in Assault on the Soul: Women in the Former Yugoslavia, ed. Sara Sharratt and Ellyn Kaschak (Binghamton, NY: Haworth Press, 1999). Human Rights Watch describes the tribunals' record as "lackluster and inconsistent on investigating and prosecuting crimes of sexual violence," in Human Rights Watch, "Bosnia: Landmark Verdicts for Rape, Torture, and Sexual Enslavement," http://www.hrw.org/en/ news $/$ list $/ 40$ ? page $=398$, accessed February 26, 2009 .

4 Beth Goldblatt and Sheila Meintjes report on varied dimensions of women's victimization and suffering in South Africa's struggle, including the "laconic and euphemistic" nature of women's reluctant admissions of their own victimization; Beth Goldblatt and Sheila Meintjes, "South African Women Demand the Truth," in What Women Do in Wartime: Gender and Conflict in Africa, ed. Meredeth Turshen and Clotilde Twagiramariya (New York and London: Zed Books, 1998), 65-66. See also Ashnie Padarath, "Woman and Violence in KwaZulu/Natal," in the same volume. Human Rights Watch reports, however, that in Sierra Leone rape was so widespread and public that there is less stigmatization of victims, and $65 \%$ of women (in a small group of 94 interviewees) reported their violation to a health care provider or healer. See Human Rights Watch, "We'll Kill You If You Cry," 52. Clearly, the perception and reality of shaming and stigmatization requires close investigation in context.

See Judith Gardam and Hilary Charlesworth, "Protection of Women in Armed Conflict," Human Rights Quarterly 22 (2000): 148-149; yet see Anne Gallagher, "Ending the Marginalization: Strategies for Incorporating Women into the United Nations Human Rights System," Human Rights Quarterly 19 (1997): 317, note 111 , on almost exclusive attention to sexual abuse in Myanmar and in Rwanda. 
women are often stigmatized or abandoned because sexual violation renders them socially unacceptable or unmarriageable, or gross sexual abuse renders them sterile or incontinent. It also happens that some harms women suffer give rise to conditions that make sexual violation more probable, as women in refugee camps lose the protection of family and neighbors, or peacekeeping troops commit rapes or patronize brothels in post-conflict settings where women are struggling to survive. Not all violations and harms suffered by women are sexual in nature. Neither are the harms women suffer always the outcome of actions intended to harm them. Women also suffer grave and irreparable losses through consequences of conflict even where women are not the primary targets of violence. When men are absent or killed in confict, for example, women may lose the male support that insures their social standing and economic survival. When men are injured, women may have to assume responsibilities for both the support of families and the care of disabled men. The disruption of local economies and food production or widespread violence may force women to move to areas where they hope food and security are available, a hope sometimes bitterly disappointed as displaced women may experience further exposure to violence and loss.

The violence and harms suffered by women in contexts of armed conflict and political repression are many and are often linked. The links create destructive synergies of loss and suffering: violence inflicted on women harms women; some harms expose women to further violence and additional harms; and serious, even life-altering or life-threatening harms result from forms of violence and repression in which women are not the primary targets of conflict yet are decisively affected by it. It is clearly a time of rising attention to the violence and harm that women suffer in conflict situations. United Nations Security Council Resolution 1325 in 2000 and the even more urgently worded Security Council Resolution 1820 in 2008 affirm active concern for both the impacts on women in armed conflict and commitment to women's participation in peace processes. ${ }^{6}$ A study of women's repression in 57 countries published in 2004 , however, can still say, "Violence against women has eluded the global human rights agenda for almost fifty years." 7 Certainly that has begun to change, and we may hope this change is decisive and irreversible. Still, the tasks of

${ }^{6}$ United Nations Security Council, Resolution 1325, October 31, 2000, S/RES/1325 (2000) and United Nations Security Council, Resolution 1820, June 19, 2008, S/RES/1820 (2008).

7 Conway Henderson, "The Political Repression of Women," Human Rights Quarterly 26 (2004): 1029. For an uncompromising critique of the gaps between the theory and practice of acknowledging and defending women's rights, see Catharine A. MacKinnon, Are Women Human? And Other International Dialogues (Cambridge, MA: Belknap Press of Harvard University Press, 2006) understanding the nature, dimensions, conditions, and consequences of violence and harm that are done to women under repression and conflict are large, varied, and relatively new.

Looking at women and violence under conditions of armed conflict or repression prompts many questions about men, women, and violence: In conditions of conflict or repression, is sexual violence the gravest violence intentionally done to women? If not, is there still good reason to put particular emphasis, in reporting and remedies, on sexual violence? Does sexual violation typically matter to women in a different way from other assault, harm, indignity, and loss that are inflicted on women by conflict? If sexual violation should not be specially emphasized, how should it be registered in assessing and repairing injuries to women, compared to other nonsexual injuries? What kinds of violence befall women as combatants and noncombatants in the same ways that they befall men? What nonsexual forms of violence or harm commonly happen to, or have particularly grave effects for, women? Are there nonsexual harms to women that are less likely to be taken seriously than comparable harms to men? Are there nonsexual kinds of violence and harm that are likely to affect women disproportionately in comparison to men?

Closely related questions arise about the gendered chaiacter of violence in conflict contexts: What are the different ways violence and harm suffered by women can be specifically linked to female gender? What gives forms of violence, including violence toward women, specifically gendered masculine meanings for male perpetrators? Are differences between gender-linked and gender-neutral violence important in identifying, acknowledging, and repairing what happens to women and men in conflict? Does it matter if gender-linked violence is consciously seen as such by the perpetrator rather than enacted without clear understanding of its gendered character? Do harms caused by violence, sexual and nonsexual, differ in meaning and impact for women and for men? Can responses to victims violated or harmed be gendered or sexualized even when the violence or harm that was done to them is not obviously sexual or gender-linked?

These questions describe a sweeping research program on gender and political violence beyond the scope of a single study. Perhaps some of these questions can be answered only by attending closely to given instances of violence in their political and social contexts. The topic is not yet deeply researched or even fully conceptualized. We need to remain open and alert to contextual and situational differences in addressing violence and harm to women in developing adequate conceptual frames, but it is urgent not to delay the task of recognizing and repairing violence toward women. In this essay, I try to organize parts of a general scheme for thinking through some questions about 
gender, violence, and harm to women in situations of conflict and repression, specifically with an eye to reparation.

Because of women's activism of the past several decades, there is now a large literature on women and violence, concerned mostly with domestic violence and rape, as well as sexual harassment and pornography. ${ }^{8}$ There is also a significant and growing literature on women's standing in international law and women's exposure to violence as a part of inter-state or intra-state political conflict. 9 This essay, however, is informed by the ultimate goal of contributing to understanding violence and harm to women as a focus of reparations in the wake of repression and conflict. I ask: How do we conceptualize harms to women with an eye to the demands of reparative justice? How must we think about harms that come about in and because of conflict from the point of view of moral obligations to repair human lives, relationships, communities, and nations? The issue is wrongful harm, loss, and suffering that would not have befallen women but for the impact of armed conflict and state repression, and that might as a result be the object of reparative action as a matter of justice. We cannot be sure in advance whether or not the categories and assumptions currently available in legal or political practice adequately respond to this issue, and the very idea of "gender-sensitive," "gender-equitable," or "gender-just" repair of violation and loss is a novelty. The schematic structure I offer is tentative and entirely provisional. Any such scheme would ideally be open-ended and adaptable: a sensitizing, heuristic, and critical instrument for approaching specific cases flexibly in their distinct political and historical context, including their particular gender roles and relationships.

${ }^{8}$ Recent sources include the National Research Council Understanding Violence Against Women, ed. Nancy A. Crowell and Ann W. Burgess (Washington, DC: National Academy Women, ed. Nancy A. Crowell and Ann W. Burgess (Washington, DC: National Academy
Press, 1996); Claire Renzetti, Jeffrey L. Edleson, and Raquel Kennedy Bergen, eds. The Sourcebook on Violence Against Women (Thousand Oaks, CA: Sage Publications, zoo1); and Michael L. Penn and Rahel Nardos, Overcoming Violence Against Women and Girls: The Intemational Campaign to Eradicate a Worldwide Problem (Lanham, MD: Rowman and Littlefield, 2003).

9 See Sheila Meinties, Anu Pillay, and Meredeth Turshen, eds. The Aftermath: Women in Post-Conflict Transformation (London and New York: Zed Books, 2001); Turshen and Twagiramariya, What Women Do In Wartime; Caroline O. N. Moser and Fiona C. Clark, eds., Victims, Perpetrators or Actors? Gender, Armed Coflict and Political Violence (London: Zed Books, 2001). Susie Jacobs, Ruth Jacobson, and Jennifer Marchbank, eds, States of Con-

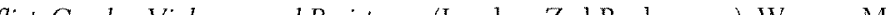
fict: Gender, Violence, and Resistance (London: Zed Books, 2000); Wenona Mary Giles and
Jennifer Hyndman, eds., Sites of Violence: Gender and Conflict Zones (Berkeley and Los Angeles: University of California Press, 2004); Sally Engle Merry, Human Rights and Gender Violence: Translating International Law into Local Justice (Chicago: University of Chicago Press, 2006); and Marie Vlachovà and Lea Biason, eds., Women in an Insecure World: Violence Against Women - Facts, Figures and Analysis. (Geneva: Geneva Centre for Democratic Control of the Armed Forces, 2005).
First, I consider some very general features of violence and harm suffered by women. I base the discussion on what we know about the structural and social inequalities and symbolic associations of women in most societies, as well as what is known about the violence women suffer typically or systematically both in everyday life and in the extremities of conflict or severe repression. I begin from the assumption that coercion of women and violence against women are normative to a greater or lesser extent in many contemporary societies. Second, I take up the consequential and contested issue of whether we can best conceive what happens to women in conflict as "on a continuum" with the nature of everyday violence against women. I argue that emphasis on a continuum of violence has indispensable uses. It is a basis for predicting forms of violence and harm women are likely to suffer, and it is essential to understanding social, institutional, and legal reforms needed in the aftermath of violence in conflict. Even so, it does not adequately capture the experience of catastrophic and lifechanging violence many women experience in these conflict situations. In the context of reparations, a focus on the victim's experience of harm and loss is essential. Third, I describe several key factors that are important in recognizing, understanding, and properly assessing harms against women in conflict, based on what is already known. Finally, I suggest that it is useful to have some general categories to keep track of the different ways in which harms befall women "because they are women," sexually, psychologically, socially, and politically; categories rooted in research on actual instances of conflict and repression help us ask the right questions. I propose four such categories: (1) gender-normative violence; (2) sex-, reproduction-, or care-specific violence; (3) gender-skewed violence; and (4) gender-multiplied violence. These categories emerge from attempting to capture the gendered dimensions of what happens to women in conflict. Yet significantly, and perhaps unsurprisingly, these categories also form the basis for a gender-comparative analysis, to which I will return.

A final word of caution: the idea of an obligation to undertake reparations, however symbolic and incomplete, for victims of political violence and repression is itself a still fairly novel idea honored mostly in the breach. The sad fact is that most victims of violence, whether male or female, adult or child, will suffer their losses - emotional, material, social, moral, and spiritual - without significant attention, much less redress. The fact that there has been, and will doubtless continue to be, massive unaddressed and unredressed suffering, however, does not diminish the importance of doing justice more fully and truly when the opportunity is there. To reckon women's losses and harms with due weight alongside men's where reparation is at issue is one case of pursuing available justice. Unless we deny that women are entitled to justice for wrongful harm, there is no reason to use the tragic incompleteness of justice 
in a violent and repressive world as an excuse not to give women their due. That women may not believe anything is due them in virtue of their violation, or may in any case be afraid or ashamed to claim it, is one of the problems to confront in conceiving violence and harm to women from the point of view of reparation.

\section{GENDER AND NORMATIVE VIOLENCE AGAINST WOMEN}

I use the terminology of normative coercion, domination, violence, and silencing of women to refer to the fact that men's domination of women and men's aspiration to control women's lives remain to a greater or lesser extent a reality in human societies. Control of women extends to women's productive, sexual, and reproductive activities and capacities and to women's speech and self-expression, from modes of dress to legal testimony to religious and political participation. The construction of gender is in this way a construction of unequal power among men and women, and of men's entitlement to power over and control of women in a variety of ways, some overt and some indirect. The claim that violence against women is "normative" draws on several decades of feminist research on gender, domination, and violence. Although the regimes of control and the methods of enforcement vary in diverse cultural and political contexts, and vary with social privilege within particular societies, men's authority over many aspects of women's lives, bodies, and social relations is the rule, not the exception. The rule of men over women is typically both expected and accepted in many or most domains of life. It is explained or legitimated through social, religious, and cultural norms. Social, moral, cultural, and religious understandings are typically intertwined in ways that justify and often naturalize male control of women. Male control is represented as proper, divinely ordained, socially functional, natural, inevitable, innate, or biologically determined or predisposed. ${ }^{10}$

Other forms of hierarchy that distribute power, authority, and opportunities in distinct and unequal ways, however, are as commonplace in human societies as is male domination. A given society's norms for acceptable and required

${ }^{10}$ Anne Fausto-Sterling, Myths of Gender: Biological Theories about Women and Men, 2nd ed. (New York: Basic Books, 1993) critically examines the biological arguments. On the cultural construction and reinforcement of masculinity in a number of contexts, see Lee H. Bowker, ed., Masculinities and Violence (Thousand Oaks, CA: Sage Publications, 1998). On men's moral complicity in rape of women as a social pattern and the idea of a "rape culture," see Larry May with Robert Strikwerda, "Rape and Collective Responsibility," in Larry May, Masculinity and Morality (Ithaca, NY: Cornell University Press, 1997). The classic theory of rape as the enforcement end of a general male regime of power remains (Susan Brownmiller, Against Our Will: Men, Women, and Rape [New York: Ballantine Books, 1993]). conduct of men and women typically differ for different and unequally privileged social, ethnic, economic, or religious groups within that society. Gender norms for women and men relatively privileged by race, ethnicity, economic resources, religion, or other factors will often differ from those for individuals of lower-ranking class, caste, race, religious, or ethnic groups in the social hierarchy. What remains consistent is that gender norms in most societies constitute positions of women at any level of social power as unequal to the positions of men of similar or higher status. At the same time, gender norms constitute forms of domination, coercion, violence, and silencing of women by men at a given level as socially legitimate: either tolerated, permissible, or required. Put simply, it is both normal and in accordance with established social "rules" that women are both unequal to men and dominated by men socially, economically, and civilly, at least within social levels. Men's everyday control of and authority over women's lives - up to and including forms of coercion and violence - is at once an expression of women's subordination, a means of sustaining male control, and a prerogative permitted by maleness as a social standing.

Gender norms are differentiated both within and between social groups of unequal privilege. ${ }^{11}$ Men of dominated or oppressed groups will not be able to enjoy positions of control over women of more privileged social groups in many contexts. Lower-class men or men of low-status or stigmatized racial, ethnic, or indigenous groups may be subject to the authority of better-educated or middle-class women in workplaces, government institutions, or legal systems. It can be a potent source of gendered humiliation or resentment that the masculinity of the lower-status man is socially neutralized by a woman's superior class status. Women of oppressed racial or economic groups may be perceived as economically or sexually more exploitable, or exploitable in different ways and with greater impunity, by more privileged men than are women of social status comparable to those men. This constitutes a heightened form of vulnerability for women who are also socially disempowered by class or race. When men compete, the ability to command the sexulity or services of women, including "other men's women," becomes a form of victory, and when the men already possess superior social power, it is a display of that superiority as a superior masculinity, as being "more of a man."

Whole groups of men and women oppressed by racial hierarchy, histories of colonization and genocide, or entrenched poverty face exposure to contempt, neglect, and abuse by official structures of power dominated by men (and

"On social groups and the complexities of interacting oppressions, see Iris Marion Young, Iustice and the Politics of Difference (Princeton: Princeton University Press, 1990). 
sometimes, to a limited extent, by women) of greater social power. Less privileged men may find that their abilities to exercise masculine prerogatives over women, at least in their own communities, are one of their most significant and valued forms of relative social power; in this regard, they can see themselves as empowered in ways comparable to men of higher social standing insofar as they retain control over "their" women. Women who belong to poor, racially stigmatized, or indigenous communities may find that solidarity with men in their communities and desires to protect these communities make it difficult to publicize or protest forms of gendered violence, coercion, and deprivation. They may see protesting domestic or sexual violence as exposing their men to powerful and hostile social authorities or betraying their men by publicly showing disrespect for men who already experience social devaluation and oppression. Sometimes women so situated see problems of domestic violence and sexual assault, though serious, as less urgent than the problems of poverty, marginalization, and political repression their communities endure. Sometimes, they may simply be afraid to face the reprisals of men in their own communities if they defy the authority of those men. At the same time, women with greater social privilege have significant social and economic interests in a status quo from which they benefit by their affiliation with and loyalty to socially privileged men and may be unwilling to jeopardize their status by reporting or condemning gender-based violence or domination. No spontaneous identification of women with each other, or solidarity among women to oppose gendered domination and violence, can be expected under these circumstances.

There are, in short, different "masculinities" and "femininities" that are not equally available to all within multiply stratified societies, and there are differing social locations created by class, race, ethnicity, indigeneity, and other factors that affect the reality and the perception of the relative power and opportunity of male and female individuals. Women's subjection in most societies to some or many forms of male control, and women's very common exposure across societies to domestic and sexual violence, are commonplace conditions, but these conditions play out in different ways and with distinct meanings and costs for women and men at different social places. The gendered meanings of power, authority, status, submission, respect - indeed, of violence itself as a display of power or right, an emblem of masculinity emerge against this complex backdrop. Men's and women's unequal social positions are constantly measured in relation to women and men of their own and other social groups. Several implications of this complex backdrop are relevant for looking at violence against women in conflict.

First, because forms of violence against women and the domination of women, sexual and otherwise, are so widely normative, it has been difficult historically for many men and women to "see" violence toward women, much less subordination of women, as an intolerable moral outrage, or, in contemporary political-legal parlance, as a gross violation of human rights. Even now, it can appear simply as what (perhaps sadly but inevitably) "happens to women," one unchangeable aspect of the "way of the world." More privileged men and women may collude in ignoring gendered power and violence within their own social group, locating gender domination or violence as a class or cultural problem afflicting primarily groups who are poor, less educated, or marginalized by race, ethnicity, or religion.

Second, the imperative of male control, at its most crude, encourages men to see women as "for" the fulfillment of men's needs for sex, service, labor, and progeny. Even fairly extraordinary violence and coercion visited on women may be considered within the norms of masculinity from the point of view of individual male perpetrators or among men in groups who legitimize and reward each other's behavior. The unusual conditions of conflict, where the use of extreme force becomes legitimate, might seem to permit treating women in ways that are not usually acceptable and that ignore established social patterns through which women may enjoy some forms of control over male access to what they offer. Sex, service, and labor may be expected and claimed more indiscriminately or through threatening and violent means that go far outside of the social constraints through which societies limit and distribute the entitlement of particular men to control particular women.

Third, and of great importance in conflict, a good deal of violence that men do to women (and that women, too, sometimes engage in or assist men in, in largely male-directed organizations and groups) functions as a way of confirming something to or among men, and becomes part of a contest among men. The contest is driven by the equation of manliness or masculinity with greater power than women, more power over women, or power over more women than some other men. Demonstrating not only the power but also the willingness or sense of entitlement to use women instrumentally, and if necessary coercively, to satisfy their desires and needs, can prove manliness to men themselves, to women, and to other men (as can the power to protect and provide for women also prove manliness in traditional patriarchal terms). The desires and needs fulfilled by using women at will, however, are not necessarily desires and needs for (or only or primarily for) sex or service, but may in fact be desires and needs to feel and appear manly in their own and other men's and women's eyes. They may also be desires and needs to be safe from reprisal from other men who expect conformity and solidarity in their presumption of masculine dominance and of dominance of women as defining masculinity. In parallel, the ability of men to provide protection for and to shield "their 
own" women from harm or violation by other men is a measure of masculinity, making the violation of other men's women an objective of opposed groups in conflict.

When aggression, dominance, and even the power to subjugate and humiliate are seen as markers of masculinity, they function in multiple ways. Men reassure each other that they are men by acting in aggressive, dominating, or violent ways toward women, creating a solidarity, a "pact," of masculinity in contrast to women. When men turn their aggression, dominance, and violence on each other, they define an order within masculinity by relative manliness that is measured by who has power over whom. The hierarchy of manliness can be either a cooperative hierarchy or a battle for dominance. Thus, violence in conflict can express, confirm, and reinforce masculinity; violence toward both women and other men is freighted with meanings and messages of manliness; and the audience for the messages men send includes other men, women, and themselves. As feminists have told us for decades, maleness is a biological configuration, but masculinity is a status and has to be claimed and affirmed by others. There are elements of gender confirmation and affiliation at stake for men in contexts of violence, and there are corresponding vulnerabilities of women to being instruments of that confirmation and affiliation by and between men. These generalizations, however, are rough guides Cultural and institutional environments may set terms for the demonstration of masculinity in diverse ways, and individuals can also express and interpret masculine behavior, within limits, in their own ways.

\section{IS THERE A "CONTINUUM" OF VIOLENCE IN CONFLICT?}

In the literature on violence against women in conflict, the trope of a "continuum" of violence is common. In the Amnesty Intemational Report 2005, violence against women in conflicts and post-conflict situations is described as "an extreme manifestation of the discrimination and inequalities women experienced in peacetime." ${ }^{\prime 2}$ Similarly, Cynthia Cockburn argues for a "connectedness between kinds and occasions of violence," which links personal to international, pre-conflict to conflict and post-conflict, and social to economic and political relations. Cockburn says "No wonder women often say, "War? Don't speak to me of war. My daily life is battlefield enough." "13 In an introduction to the collection containing Cockburn's paper, editors Wenona Mary Giles and Jennifer Hyndman comment that Cockburn's continuum stretches

${ }^{12}$ Amnesty International Report 2005, Regional Overview 2004, Africa, http://www.amnesty.org/ en/library/info/POLıo/oo1/2005, accessed February 26, 2009.

13 Cynthia Cockburn, "The Continuum of Violence: A Gendered Perspective on War and Peace," in Sites of Violence, Giles and Hyndman, 43. from "the gender violence of everyday life, through the structural violence of economic systems that sustain inequalities and the repressive policing of dictatorial regimes, to the armed conflict of open warfare." ${ }_{14}$

It is certainly true that the accumulated sophistication of gender analysis of violence against women that feminists have developed since the 1960 s provides a framework indispensable for understanding how gender structures and legitimates many forms of male violence against women. A unifying explanation of gender oppression, male domination, and violence against women at a high level of generality serves important purposes of pre-conflict prediction and prevention and of post-conflict policy analysis and reform. Even so, it does not fully capture the experience of women who suffer extreme forms of violence in conflict. A theoretical explanation that identifies patterns and similarities for purposes of analysis does not necessarily reflect the shattering experience of discontinuity, the sense of enormity and outrage, or the terror, despair, and social ruin of victims in many actual instances of violence in conflict. What theory reconstructs conceptually as a continuum may not correspond to victims' shocking and traumatizing experiences of violence in conflict and repression situations. This is the reported experience of many victims of public mass rape, domestic enslavement, or sexual mutilation, even where these women's ordinary lives embodied significant components of harsh male control, physical cruelty, coercion, sexual assault, and silencing. The startling Human Rights Watch report on sexual violence against women in Sierra Leone, "We'll Kill You If You Cry," reports the very low pre-conflict status of women as a background factor, yet details graphically the extraordinary pain, loss, physical damage, and despair that women violated in conflict experienced. In a perspective that looks at violence with an eye to reparation for victims, the individual victim's experience of catastrophic discontinuity needs to hold a central place. ${ }^{15}$

If there are typically forms or levels of violence that are normative against women in many societies, what makes cases of violation in conflict often

${ }^{4}$ Wenona Mary Giles and Jemnifer Hyndman, "Introduction," in Sites of Violence, Giles and Hyndman, 10. For a more complex use of the continuum, see Caroline O. N. Moser, "The Gendered Continuum of Violence and Conflict: An Operational Framework," in Victims, Perpetrators or Actors? Moser and Clark.

${ }_{15}$ There is a corresponding danger here of overgeneralizing about victim perspectives. Individual cases call for close attention to victims' own reports and individual assessments in context, but there are also problems of voice that can make it difficult for victims to represent their experiences. I discuss briefly the uncertainties surrounding whether women's own preferences and understandings are completely "colonized" by oppressive circumstances in Margaret Urban Walker, "Truth and Voice in Women's Rights," in Recognition, Responsibility, and Rights: Feminist Ethics and Social Theory, ed. Hilde L. Nelson and Robin N. Fiore (Lanham, MD: Rowman and Littlefield, 2003) 
catastrophic for individuals? The key is remembering that normative social behaviors and positions, by their nature, constitute an order, and that order is in many and profound ways suspended, deformed, or destroyed in conflict situations. If everyday life in many instances is a limiting, cruel, demeaning, or defeating order for women, it is nonetheless one around which women build their lives, make their choices and compromises, and determine their behaviors. So, the idea of normative coercion and violence does not imply that all forms of coercion and violence, no matter how extreme, are to a greater or lesser extent familiar to or expected by women. On the contrary, a woman who is bound to accept uncomplainingly her husband's beatings and marital rape is not thereby prepared for being beaten by strangers, raped repeatedly in public, being raped by a male child (perhaps her own, under threat of death), or being kidnapped, terrorized by physical abuse, and held captive as a sexual and domestic servant of an enemy military. Women who are accustomed to the harsh physical labor required to fulfill their everyday domestic and care-giving responsibilities are not thereby prepared for the threats and hardships of sustaining their families under conditions of displacement and in the absence of material resources and social networks. Even painful and mutilating practices of genital cutting widely practiced in some societies, creating grave forms of physical pain and disability, are socially ritualized and integrated into marriage and family practices that reproduce a cultural order (even if the order is in this respect a cruel one). This is very unlike rape and sexual mutilation intended to soil and ruin, producing social rejection.

The indignities, abuses, injuries, and violations increasingly documented in conflict are often not normal or normative from the victims' point of view. Some of the most intense shame and despair women report as a result of sexual violation by enemies and strangers in conflict is precisely the sense of having been irrevocably spoiled and damaged, thereby rendered unsuitable for the normal life these women previously lived, even if that was itself a life of significant or severe sexual, economic, and social restriction or subjugation. Women very often do not experience severe violations merely as more intense forms of what they are used to, and differences of economic class, race, ethnicity, or religious culture will likely affect women's perceptions of continuities and discontinuities of male dominance in peacetime and in conflict. ${ }^{6}$ This

${ }^{16}$ Judy El-Bushra analyzes several African conflicts emphasizing the importance to women of "respect" even under conditions of domination and exploitation: "They are willing to pay for the public acknowledgment that they make important contributions to society, and for the removal of doubt about the security of their marital and other relationships"; Judy ElBushra, "Transforming Conflict: Some Thoughts on a Gendered Understanding of Conflict Processes," in States of Conflict, Jacobs et al., 83. is not only an aspect of women's experience, however; it is a fact about what can and does regularly happen in conflict. Just as in combat generally, where unnecessary violence, atrocity, and unjustified killing happen, male coercion and violence in conflict can become disengaged from the larger structure of social norms that limit and channel gender domination within normative boundaries. Women can then no longer rely on these limits and what protection they might offer, and they may find they are exposed to an extreme and nightmarish discontinuity. As United Nations relief official Jan Egeland recently said of rape as a weapon of war, "There has been such a deterioration in the social and moral fabric that sexual violence has become a method of war, and not just soldiers do it, many civilians do, too. . . It's like there are no barriers anymore." ${ }^{17}$ And it is part of the aim of violence toward women in conflict, used increasingly as a strategy of war, to disrupt and destroy a social order and leave isolation, defeat, and terror in its place.

The theoretical construct of a continuum of violence nonetheless has a central role to play in forecasting the exposure of women to particular forms of loss, coercion, and violence and in making good guarantees of nonrepetition in the wake of violent conflict and repression. Violence against women, so studies suggest, is primarily about control, where controlling women - either one's own or those of other men - is emblematic of masculine power. ${ }^{18}$ This factor predicts features of pre-conflict, conflict, and post-conflict situations for women as targets of violence. The pre-conflict condition of militarization often includes a retrenchment and sharp reiteration of masculine and feminine roles, with men as leaders, and heightens a competitive but comradely masculinity, with emphasis on hardness and aggression. During conflict, some of the forms of coercion and violence that are normative in ordinary life are likely to be the ones that escalate beyond normative bounds: routine and extreme sexual abuse and in certain conditions domestic enslavement of women, although on a massive scale or with more gratuitous humiliation and physical harm, are depressingly predictable. Post-conflict, as is now increasingly reported, there is an increase in levels of domestic and social violence toward women. ${ }^{19}$ Men

17 Warren Hoge, "U.N. Relief Official Condemns Use of Rape in African Wars," The New York Times, June 22, 2005

${ }^{18}$ See National Research Council, Understanding Violence Against Women. On a study in the Eastern Cape that finds it is not violence per se that constitutes masculinity but rather the leverage it gives in controlling women, see Tina Sideris, "Rape in War and Peace: Social Context, Gender, Power and Identity," in The Aftermath, Meintjes et al., 145.

19 Colleen Duggan and Adila Abusharaf, "Reparation of Sexual Violence and Democratic Transition: In Search of Gender Justice," in The Handbook of Reparations, ed. Pablo de Greiff (New York: Oxford University Press, 2006). 
after conflict need to reassert control over women (and, not incidentally, over themselves, after what may have been traumatizing experiences of violence both done and suffered). They also need to reestablish their place in masculine groups and hierarchies. Their stake in doing so may be enlarged if men are not fully able to enact other forms of masculine behavior, like economic provision and social leadership. Poor men, disenfranchised men, and jobless men may be tempted to control women as the principal expression of masculinity when their demobilization offers little in the way of masculine achievement or affirmation, perhaps not even decent employment. They might control and violate women because that is power and it might be the only power they can exercise. More powerful men, on the other hand, also need to exhibit their control of women, because that is a form of power that confirms and completes their other forms of social power, signifying heteronormative "manliness."

From the point of view of impending or existing conflict, enough is now known to predict women's gendered vulnerability to specific forms of loss and violence in conflict and women's lesser access to resources, limited mobility, inadequate political representation, and unequal access to legal mechanisms From the point of view of comprehensive programs of reparations, for which the international standards include guarantees of nonrepetition for those violated, it is crucial to understand that women are very likely to face not only "ordinary" levels of violence in conflict and its aftermath, but also escalated everyday violence. Thus, the continuum identifies areas for preventive and protective concem, especially legal and social provision for women's rights and safety, that fall within the scope of some reparative measures. It cautions against reparation processes that might be undermined or exploited by continuing vulnerability of women to male control and violence. It helps us understand why, even at extremities, abuse of women can be so easily ignored.

The continuum of male violence toward and domination of women helps us think about necessary social, political, and legal changes that are needed to confront violence against women within conflict and everyday life, and the links between these. Focus on the experience of victims, however, foregrounds the terror of extreme violence in conflict that profoundly disrupts social controls that normally contain male dominance so that even a harsh gendered social order still has its limits and rules. Several specially commissioned reports in a recent study by the International Center for Transitional Justice note a pattern in post-conflict situations, where women's rights organizations were more concerned with forward-looking legal and social change to restructure women's daily lives, whereas victim organizations often did not focus specifically on women who suffered in conflict but rather on women as relatives and dependents of those harmed. ${ }^{20}$ The forward-looking agenda of advocacy for women's rights can leave behind victims, just as a focus on men as primary victims and women as survivors can leave female victims of direct violence with no place to turn, or with inadequate acknowledgment of their terrible losses. As Ruth Rubio-Marin's contribution to this volume argues, reparations must express a commitment to a rights-respecting political order for all citizens while at the same time acknowledging and addressing wrongs and harms to individuals who are violated.

\section{SIGNIFICANT DIMENSIONS OF VIOLENCE AGAINST WOMEN}

What are some of the common patterns of violence that afflict women in armed conflict and repression? I explore a variety of factors involving gender that appear in research on conflict situations. These common patterns alert us to where and for what we should look in identifying violence toward women and harms women suffer.

\section{Male Exchanges through Violence toward Women}

Cockburn writes that "male-dominant systems involve a hierarchy between men, producing different and unequal masculinities, always defined in relation not only to each other but to women." ${ }^{21}$ In this way men's normative control of women becomes a means of solidarity among men allied to each other and becomes a strategy of humiliating and expressing dominance over the male opposition in conflict. When men acknowledge and endorse each other's possession, protection, and control of women, they confirm each other's masculinity. The same principle of male control also accommodates and serves to express differences among men in a hierarchy of power and status. ${ }^{22}$ When

20 On the gap between advocacy for women generally and advocacy for women victims, see Beth Goldblatt, "Evaluating the Gender Content of Reparations: Lessons from South Africa," in What Happened to the Women? Gender and Reparations for Human Rights Violations, ed. Ruth Rubio-Marín (New York: Social Science Research Council, 2006), 56-57; also in the same volume, see Claudia Paz y Paz Bailey, "Guatemala: Gender and Reparations for Human Rights Violations," 131, note 78; Julie Guillerot, "Linking Gender and Reparations in Peru: A Failed Opportunity" 145-149; Heidy Rombouts, "Women and Reparations in Rwanda: A Long Path to Travel," 205-206; and Galuh Wandita, Karen Campbell-Nelson, and Manuela Leong Pereira, "Learning to Engender Reparations in Timor-Leste: Reaching Out to Female Victims," 292-296. Jamesina King, "Gender and Reparations in Sierra Leone: The Wounds of War Remain Open," in the same volume, 253-256, tells a somewhat different story.

${ }^{21}$ Cynthia Cockburn, "The Continuum of Violence," 29, citing Carol Pateman.

22 A Human Rights Watch report on Sierra Leone describes the result of a rebel commander's attempt to spare an old woman from rape by troupes: "But the other rebels got annoyed and 
men violently appropriate and violate women who are supposed to be within the possession, protection, and control of other men, they subordinate or challenge the other men's manliness, expressed in their ability to remain in control of their women. Women are thus a medium through which men transact exchanges signifying relative power, alliance, or opposition.

The pattern is unsettling in its simplicity and catastrophic for women where men enter into wholesale and violent conflict; there appropriation, violation, and abuse of women are at once practically effective in disrupting social life and its material maintenance but also expressively effective in signaling disrespect, disdain, and contempt for other men. ${ }^{23}$ Though it is true that men are also raped or sexually abused by men in conflict or detention, the meaning of this abuse is clearly that the man sexually used becomes an unmanly (lesser) man or even "a woman," a meaning common in the rape of men in prison environments, but also in the rape and sexual abuse of men by men in armed conflict and repression. ${ }^{24}$ Women, too, participate in these symbolic exchanges that take all too literal forms, where women may express the dominance of "their" men, and the higher social status they derive from it, by their ability to command or to evade the authority of other lowering-ranking men, or to participate in subjecting enemy men to sexual humiliation. When women abuse women, they may also enhance and exhibit their position as protected and inviolate by participating in rendering other women used and demeaned. In an implacable hierarchy enforced by coercion and violence, women too will claim places of relative power. ${ }^{25}$ The common denominator is that in most human groups an exercise of power, especially sexual power, over women is a symbolically masculine and superordinate position, whereas being the object of sexual control and coercion is feminine and subordinate. The more benign aspect of this gendered symbolic order is the protective face of masculinity, with masculine obligations to support and protect; the uglier aspect is men's sense of entitlement to women's bodies and labor for "individual

started insulting the commander saying, 'Fine, you can fuck any women you want, anytime you want, but now that we have one we want, you say no.' The commander finally said that they could go ahead so all five rebels, including a small boy of fifteen years, raped her." Human Rights Watch, "We'll Kill You If You Cry," 37.

23 Dorothy Q. Thomas and Regan E. Ralph, "Rape in War: Challenging the Tradition of Impunity," SAIS Review (1994): 82-99.

${ }^{24}$ For analysis of the meanings of men's rape and sexual mutilation of men in the former Yugoslavia, see Dubravka Zarkov, "The Body of the Other Man: Sexual Violence and Construction of Masculinity, Sexuality and Ethnicity in Croatian Media," in Victims, Perpetrators or Actors? Moser and Clark. See also Sandesh Sivakumaran, "Male/Male Rape and the 'Taint' of Homosexuality," Human Rights Quarterly 27 (2005): 1274-1306.

${ }^{25}$ On women's roles in domestic, caste, and religious violence, see Parita Mukta, "Gender, Community, Nation: The Myth of Innocence," in States of Conflict, Jacobs et al. gratification or political ends." 26 Both aspects, however, are rooted in widespread beliefs that masculinity requires and is measured by control of and access to women.

\section{The Symbolism of Gender and Punishment of Women's (and Men's) Gender Transgression}

A symbolic dimension of gender invests women and men with culturally significant meanings. There are considerable similarities in the gendered meanings of womanhood that traverse cultural contexts, and these can be adapted to specific situations in which women become the medium for representing cultural identity or its transformations. Yuval-Davis says, "Women often become the symbolic bearers of modernity. Unveiling women in Ata Turk's revolution of 1917, which was aimed at constructing Turkey as a modern nation-state, was as important as veiling them has been to Muslim fundamentalists in the contemporary Middle East."27 In another example, a society's admitting or inducting women into its armed forces is also a symbolically freighted move that can signify civic equality but also society-wide militarization. In a variety of ways women function as "iconic representations" of cultural, ethnic, or national identity. ${ }^{28}$

Women are often vehicles for the representation of a nation's quest for independence and freedom from incursion or violation by an external power, or for an ethnic or religious group's reiteration of its defining "tradition." V. Spike Peterson and Anne Sisson Runyan call "gendered nationalism" the "manipulation of gender identities and symbols and gendered divisions of power, labor, and resources" that are recruited to the task of winning wars of national liberation and establishing independence. ${ }^{29}$ Women's purity symbolizes the inviolability of a community and the power of its men to protect its boundaries, making sexual violence by outside men a humiliation of individual women, a violation of communal integrity, and a shaming defeat of men in their protective roles. Women also commonly symbolize "home and hearth," the stability and continuity of a community's daily life, making the killing and violation

${ }^{26}$ Amnesty International, "Violence Against Women: A Fact Sheet," http://www.amnestyusa.org/ women/violence/index.html, accessed February 26, 2009.

27 Niva Yuval-Davis, "Gender, the Nationalist Imagination, War, and Peace," in Sites of Violence, Giles and Hyndman, 172.

${ }^{28}$ Giles and Hyndman, "Introduction," in Sites of Violence, Giles and Hyndman, 9, quoting Amartya Sen.

29 V. Spike Peterson and Anne Sisson Runyan, Global Gender Issues (Boulder, CO: Westview Press, 1993), 132-133. See also Cynthia Fnloe, Manewvers: The International Politics of Militarizing Women's Lives (Berkeley and Los Angeles: University of California Press, 2000). 
of women an assault on the bases of social order. $3^{\circ} \mathrm{Men}$, too, are bearers of symbolic meaning, for example, that of the warrior or protector. Like material resources, however, cultural symbolic resources are apt to be controlled in many social settings by powerful men rather than by women. The protection or the abuse of women, both in times of conflict and repression and in the aftermath, will invariably be seen as statements not only about women and men, but about society's moral, political, and cultural values and identity. So charged are the social and cultural meanings invested in both the violation and protection of women that the suffering and human rights of individual women may be overshadowed by social struggles over these meanings.

Transgression by women of their socially assigned meanings provokes forms of repression and violence that are anything but symbolic. Post-conflict reports from Peru, Guatemala, Timor-Leste, and South Africa include assassination, disappearance, rape, torture, harassment, and detention of women for daring to engage in political activity or community organization, or taking active roles in pursuing the mistreatment or disappearance of male relatives. ${ }^{13}$ Women's confinement to domestic or familial spheres and the definition of politics as a male domain, as well as the presumption that women will not contest or confront male authority, constitute these activities as intolerable transgressions of women's gendered places and their required subservience to male authorities. Women who show resilience under the hands of male torturers may provoke additional punishment. Furthermore, women fare no better when they are seen as mere extensions of their male relatives. They have been used as hostages, or are detained and tortured, to influence or to extract information on their male relatives. Men, too, may suffer reprisals or may be threatened for failing to demonstrate their own masculinity and to affirm other men's masculinity by sharing in the control and use of women. Just as men may suffer penalties of ridicule or exclusion for sharing power and daily responsibilities with women equitably in daily life, so men can be penalized or punished for refusing to participate in or to condone violence toward women in contexts of conflict. There are powerful pressures both within men and between men to assert and mutually affirm dominating masculinity.

\section{Specifically Sexual or Reproductive Coercion, Harm,} Torture, and Mutilation

Women in some conflict contexts suffer forms of violence similar to those afflicting men, like extrajudicial execution, illegal detention, beatings, and

30 Tina Sideris, "Rape in War and Peace," in The Aftermath, Meintjes et al., 146-149.

${ }^{31}$ See Rubio-Marin, What Happened to the Women?, for reports on Peru, Guatemala, South Africa, and Timor-Leste. torture. ${ }^{32}$ In many cases, however, violence afflicting women includes abuse, torture, terror, and mutilation of women that is specifically sexual in nature, or that targets women's reproductive and sexual parts, not infrequently causing irreparable damage and reproductive disability or inability. In addition to rape and other sexual abuse, reports of sexual mutilation, forced prostitution, sexual slavery, forced pregnancy, forced abortion, forced sterilization, and sexual torture are reported in many contemporary conflict contexts, and rapes include gang rapes, rapes with objects, public rapes, and sometimes men forced to rape women who are related to them. ${ }^{33}$ Also reported are tendencies to sexualize the torture of women, raping them, assaulting their breasts, genitals, and reproductive organs, and threatening to do so. From Sierra Leone, Guatemala, and Rwanda come reports of pregnant women's bellies sliced open and fetuses cut out.

Much reported sexual violence surely has instrumental purposes - to terrorize, subjugate, and demoralize women and their communities, and to punish women for political or autonomous activity. In Guatemala, where rape of indigenous women was sometimes ' massive' and/or 'multiple,' performed in public squares or markets, to be seen by the whole community or the victims' families" according to Claudia Paz y Paz Bailey, rape was a form of genocidal violence and was one part of a specific and repeated pattern of massacre and destruction of indigenous communities for which the Guatemalan army trained its soldiers. 34 Contemporary patterns of mass rape and sexual mutilation leave no doubt that mass sexual violence is a tool of war, as perhaps historically, in reality, it has always been. Yet the sheer extremity and grotesque cruelty of sexual violence reported in many cases, even if tolerated, encouraged, or required by military, militia, or insurgency authorities, suggests also powerful desires of men to exert total and brutal power over women and engage in sadistic destruction of women's bodies and persons. Postmortem sexual mutilations are not entirely a pragmatic practice, despite their use in terrorizing populations. It seems that under conditions of superior power and extreme violence, just as some combatants will commit other atrocities and massacres out of frustration or with a sense of explosive exhilaration, so too will some men (and, in some cases, women) engage in pointless torture, sexual injury,

32 Guillerot, for example, reports that Peru's Truth and Reconciliation Commission found the crimes most frequently reported by or about female victims were murders and extrajudicial executions $(50 \%)$, followed by detentions $(27 \%)$, tortures $(23 \%)$, kidnappings ( $17 \%)$, disappearances $(16 \%)$, and rapes $(10 \%)$; Guillerot, $14^{1-142}$. Guillerot of course notes the underreporting likely to occur in cases of sexual violence.

33 See Paz y Paz Bailey, Rombouts, King, and Wandita et al.

34 See Paz y Paz Bailey, especially 94-101, quote page 97; see also Wandita et al., 290, on strategic uses of sexual violence in Timor-Leste. 
and humiliation of women. 35 This fact is perhaps less to be explained than it is to be noted, so that its prevention becomes a priority and the costs of engaging in this kind of violence are made steep, instead of accepted as inevitable or as "collateral damage" to be expected in conflict. In any case, both the coldly planned military and political dimensions, as well as the toleration of excesses, need to be kept in mind.

In some situations, reported sexual violence seems to be almost exclusively directed at women, but no one doubts that sexual violence by men against men occurs and is probably even more underreported than sexual violence toward women. $3^{6}$ This is a topic that requires further exploration, both in terms of its gendered meaning and impact for and on men, and for its actual occurrence and the conditions under which male-on-male sexual violence occurs. At present, men's sexual violence against women is widely reported and largely predictable; it calls for specific and immediate preventive and deterrent action for that reason.

\section{Targeting Women's Mothering}

The vulnerability of women to forms of torment and torture because of their maternal hopes, attachments, and responsibilities deserves separate mention. Diverse forms of reproductive coercion and violation are a part of many contemporary conflicts. Men's ordinary control of women's fertility, through marriage practices and conjugal control, including marital rape and prohibiting or forcing contraception or abortion, is within the category of normative coercion in many societies. Forced pregnancy, forced abortion or sterilization, and forced cohabitation with almost inevitable results of pregnancy are among the forms of reproductive abuse reported in contexts of conflict. These are forms of both physical and psychological violation, with potentially irreversible and dire social consequences, as when women must deal with the stigma of bearing not only children outside marriage, but also children of enemies and those who have engaged in genocide against the women's group, as in the Rwandan and Guatemalan situations. Women's maternal roles and attachments can be exploited to produce anguish and terror; torturers may threaten women's children, and soldiers may abduct or massacre their children as well as raping or sexually mutilating and humiliating the women themselves. Women may

35 On killing frenzy in close combat, see Jonathan Glover, Humanity: A Moral History of the Twentieth Century (New Haven: Yale University Press, 2000), 52-57. For some gruesome examples of postmortem sexual mutilation in Guatemala, see Paz y Paz Bailey, 98 and 127 notes 34 and 35

$3^{6}$ A recent study is Sivakumaran, "Male/Male Rape." have to bear the torment of their inability to protect their daughters from abduction and sexual violence and their sons from forced conscription. Population displacements render women unable to care properly for children and frail elders for whom women consider themselves responsible. ${ }^{37}$

The situation of women abducted into domestic and sexual enslavement in which they have given birth presents grave difficulties for the reintegration of both women and their children. A 2002 UNICEF report estimates that although $30 \%$ of child soldiers in Sierra Leone were girls, only $8 \%$ benefited from the disarmament, demobilization, and reintegration (DDR) program, because the girls were perceived, and perceived themselves, as "sex and domestic slaves." Jamesina King reports the creation in Sierra Leone of a governmental family-tracing program to assist abducted children, but no reparation measures have yet been enacted. $3^{8}$ The long-term consequences of rape in conflict include disabilities that cause fistula, reproductive injuries, infertility, and the infection of women with AIDS, which not only cause grave suffering but also affect women's social acceptability, marriageability, and childbearing possibilities. Women raped or subjected to sexual slavery have given birth to children for whom they may not be able, or may not wish, to care. ${ }^{39}$ Finally, there are cases of fraudulent adoption of infants taken from women murdered or in detention, raising issues of support and search services, as well as the irreparable disruption or loss of familial relationship. $4^{\circ}$

\section{Women and Property}

As weighted as gender roles and positions are with symbolism, especially meanings invested in women as sexual beings and as mothers, women also hold and control property and resources and are a major productive force in many local economies. Judith Gardam and Hilary Charlesworth, writing on the protection of women in armed conflict, urge us to take account of women in "the various roles [women] perform in societies and not merely as mothers and sexual objects." 41 Women are a key productive force in the daily survival and reproduction of communities. Yet often woinen by law, custom,

37 Examples in this category are found in Goldblatt, 54; Paz y Paz Bailey, 97 and 126, note 23; Rombouts, 208; and King, 251.

$3^{8}$ King, 274 .

39 King, 275-276.

$4^{\circ}$ Human Rights Watch, "Argentina: Reluctant Partner: The Argentine Government's Failure to Back Trials of Human Rights Violators," Human Rights Watch Report 13, no. 5 (December 2001), Section V, http://www.hrw.org/reports/2001/argentina/index.html, accessed February 26, 2009.

${ }^{41}$ Gardam and Charlesworth, "Protection of Women in Armed Conflict," 166. 
and religion do not enjoy control over property and wealth comparable to men of similar class location, and violent upheavals that disrupt and transform traditional divisions of labor, power, and ownership, or that involve relocations, often result in dramatic losses for women economically, or in women's being unable to assert rights to property. Despite a reform of inheritance law adopted in 1999, Rwandan women and girls are still denied equal rights to land under Rwandan customary law in an agrarian society in which survival is determined by access to land..$^{42}$ Remaining in or returning to rural villages to coexist with perpetrators of rape and murder are not conditions under which women are likely to assert their rights to land, especially where this means asserting rights to land against men. ${ }^{43}$ Official statistics used to define policies of reconstruction may ignore households run de facto by women when husbands are absent or missing. 44 Women may find their land or jobs awarded to demobilized combatants. 45 At the same time, it is virtually always true that women continue to bear responsibility for the care of children, relatives, and elders.

With current, long-delayed, and still not fully effective attention focused on sexual violence toward women in political conflict, there is still the possibility that sexual violence will take so much of the stage that women's losses of livelihood, land, and wealth may be eclipsed by the more shocking facts of mass rape, sexualized torture and mutilation, and sexual enslavement. It would be a terrible irony if women at long last receive adequate recognition of victimization by sexual violence in conflict, only to be sexualized as victims, so that their economic and material losses receive little weight. Where women have been abducted and enslaved for sexual use, they also have often been victims of forced labor, a human rights violation and form of exploitation that should be recognized and redressed specifically as such. It should not be assumed, however, that sexual violence and unjust destruction or appropriation of women's property are separate kinds of violence that only circumstantially interact. Whereas men coercively appropriate both daily toil and sex from women, Meredith Turshen effectively argues from the African context that "in civil wars, armies also use rape systematically to strip women of their economic and political assets. Women's assets reside in the first instance in their productive

42 Human Rights Watch, "Struggling to Survive: Barriers to Justice for Rape Victims in Rwanda," Human Rights Watch Report 16, no. 10 (September 2004): 11-12. See also Rombouts, 204-205. 43 Meredeth Turshen, "Women's War Stories," and Clotilde Twagiramariya and Meredeth Turshen, "Favours' to Give and 'Consenting' Victims: The Sexual Political of Survival in Rwanda," both in What Women Do in Wartime, Turshen and Twagiramariya, 8, 109, and 112. See also Rombouts, 231-233

4 See Duggan and Abusharaf, "Reparation of Sexual Violence."

45 Codou Bop, "Women in Conflicts, Their Gains and Losses," in The Aftermath, Meintjes et al., 29 . and reproductive labour power and in the second instance in their possessions and their access to valuable assets such as land and livestock." 46 It is imperative that women who suffer violence and harm in conflict be an integral part of processes that define the nature and relative attention to sexual and nonsexual harms, and that these processes anticipate and identify the complex and bidirectional relationships between sexual abuse and material dispossession of women.

\section{Women as/and Social Capital}

Social capital accumulates at those points where trust in human connections and networks of communication make cooperation and material resources available to men and women. Social capital is defined as "the rules, norms, obligations, reciprocity and trust embedded in social relations, social structures and a society's institutional arrangements that enable its members to achieve their individual and community objectives." 47 Both men and women are utterly dependent on, and contribute to the production of, social capital embodied in formal institutions and informal networks. Social capital is the human connective tissue that holds households, relationships, localities, and societies together. Women are often seen as symbolizing social capital - the daily order of communal life - but women are in fact concretely indispensable to the maintenance of that order, both materially and socially, through labor as well as maintenance of day-to-day cooperative relationships and informal social networks. This, once again, makes women choice targets for violence in conflict or under repression, where the goal of "the disruption of social arrangements, activities, and institutions that give people a sense of belonging and meaning" is served by targeting women for death, social disgrace, and communal exclusion..$^{8}$ Sexual violence is increasingly a strategy for "undermining cultural values and community relationships, destroying the ties that hold society together." 49 Conflict that destroys the infrastructures of electricity, transport, and health care may limit women's mobility; creating rivalry over scarce resources, such as water, can set neighbors against each other; political terror can isolate individuals and households within communities where fear

$4^{6}$ Meredeth Turshen, "The Political Economy of Rape," in Victims, Perpetrators or Actors? Moser and Clark, 56.

47 Moser, "The Gendered Continuum," 43. Moser provides analysis of different forms of social capital and their availability or impact on men and women.

$4^{8}$ The phrase is from Anu Pillay, "Violence Against Women in the Aftermath," in The Aftermath, Meintjes et al., 57.

49 Human Rights Watch, "We'll Kill You If You Cry," 4. Case studies in Rubio-Marín, What Happened to the Women?, include uses of sexual violence for demoralization of communities. 
and mutual distrust become survival skills..$^{\circ}$ All these kinds of conflict and repression inhibit the maintenance of social capital or destroy it. Women's activities and relationships are both generators of social capital and are dependent on its sustainability. The losses that women incur in these dimensions, and the value to women of opportunities to repair and create networks and relationships, are important issues for reparation agendas that seek to address women's wrongful losses. This is also an area in which the creation or reconstruction of collective resources and communal institutions may be relevan in reparations schemes. Heidy Rombouts reports the delicate social ecology of life on the Rwandan hills, and the urgency of considering reparations measures that respect fragile social balances that maintain women's lives. ${ }^{51}$ Competition among women, and among and within communities, for scarce resources means that women may not readily sympathize with other women who are victims, and that female victims may not necessarily stand together to seek repair.

\section{Quandaries of Shame and Exclusion}

It is important to stress that shame, humiliation, and despair are common reactions of victims of violence, both male and female. Research on traumatic violence, political and criminal, shows that victims experience an intense and overwhelming cluster of emotions after suffering violence or the traumatic loss of loved ones..$^{2}$ Furthermore, victims crave and deserve validation of the fact of their injury and the wrongfulness of what was done to them. When victims are instead shumned, ignored, blamed, or punished, they suffer not only isolation and despair, but a form of normative abandonment, a realization that rules and restraints that might have protected them are not enforced in their case and that they themselves do not matter. Exclusion and abandonment are additional

$5^{5}$ Moser, 43-46. See also Caroline O. N. Moser and Cathy Mcllwaine, "Gender and Social Capital in Contexts of Political Violence: Community Perceptions from Colombia and Guatemala," in Victims, Perpetrators or Actors? Moser and Clark.

${ }^{51}$ Rombouts, 231-233.

52 Ronnie Janoff-Bulman, Shattered Assumptions (New York: The Free Press, 1992), 79-80, notes research that human-induced victimization is apt to be humiliating, having made one helpless or overwhelmed before another person, challenging the victim's "competence and independence" Judith Herman. Trauma and Recovery. The Aftermath of Violence - Fom Domestic Abuse to Political Terror (New York: Basic Books, 1997), 33, also discusses humiliation and grief that result from exposure to "the extremities of helplessness and terror." See also Susan Brison, Aftermath (Princeton: Princeton University Press, 2002) on massively altered senses of self and self-control of victims of violence, and Thomas J. Scheff, Bloody Revenge: Emotions, Nationalism and War (Lincoln, NE: iUniverse.com, Inc., 2000) on the occurrence of shame in response to violation and the dangers of aggressive rage that arises, or can be induced, as a defensive response to that shame. emotional, social, psychological, and moral injuries that undermine or destroy trust and hope in those who have already suffered terrible violations. 53

In the case of women and sexual violence, notoriously, victims may become the target of shaming, blame, and disdain. This is no less true when the sexual violence occurs in political conflict or under repression, both as spontaneous acts of individuals and also, now endemically, as a strategy of genocide, torture, terror, and demoralization of populations. One might hope for communities solidarity with women who are brutally and ruthlessly used by enemies in the context of conflict, but it appears that this is not usually the case. Every one of the country studies in Ruth Rubio-Marin's What Happened to the Women? reports problems of stigmatization, rejection, fear, and shame for raped and sexually abused women, whether the reported incidence of sexual violence is great or less frequent. ${ }^{54}$ The shame of women who correctly assume that they will be rejected, scorned, shunned, or driven out by families and communities after suffering sexual violation is well documented. The likelihood of this result is precisely one of the known motivations for those using rape as a strategy to demoralize and break down communities. ${ }^{55}$ Even when families are willing to accept and support women who have suffered rape, abduction, and pregnancy due to rape, their larger communities may see these women as stained, unmarriageable, and under suspicion of complicity with the aggressors. ${ }^{6}$ The degree to which this is so, however, can vary with the publicity and breadth of sexual violation as well as specific political and cultural contexts.

Even women who do not blame themselves for their violation, and understand that they were raped as a strategy of conflict, may nevertheless experience themselves as "spoiled, worthless, and devalued" because of deep associations between women's dignity and their sexual purity and propriety. ${ }^{57}$ Rape and

53 Psychologists call this a "second wound." Janoff-Bulman cites Martin Symonds on the "second injury," in Shattered Assumptions, 147. On the "second wound" and the "conspiracy of silence," see also Yael Danieli, "Introduction," International Handbook of Multigenerational Legacies of Trauma (New York: Plenum Press, 1998), 7. On the complexities of victim response and the importance of validation, see Margaret Urban Walker, "The Cycle of Violence," Journal of Human Rights 5 (2006): 81-105.

54 See Goldblatt, 54-55; Paz y Paz Bailey, 100 and 128, note 50; Guillerot, 141 and $14^{6-147}$ Rombouts, 208-209 and 213; King, 263 and 273; and Wandita et al., 292.

55 Thomas and Ralph, "Rape in War" explains the strategic function of rape that exploits women's "protected status" to shame communities as well as individual victims.

$5^{6}$ Melanie Thernstrom "Charlotte, Grace, Janet and Caroline Come Home" The Now York Times Magazine, May 8, 2005, 34-39, reports the situation of four young women who escaped abduction and violent captivity by the Lord's Resistance Army in northern Uganda, where families support them but social reintegration remains tenuous.

57 Sideris, 150 , discussing interviews with Mozambican women. See also Human Rights Watch, "We'll Kill You If You Cry" on the profound shame of women even while many are welcomed back by families. 
other forms of sexual indignity and atrocity (such as coerced incestuous rape or mutilation of genitals) are often committed publicly to add to the future humiliation of victims under the eyes of their communities. Further, abduction of women and children who are made to serve as combatants or coerced into sexual use and domestic service, and who are commonly "initiated" and subjugated by being forced to kill for and otherwise serve the enemy or insurgent army, has become widespread. Melanie Thernstrom reports of abductees in northern Uganda that "they cannot go back to villages where people recall the night they returned with the rebels and massacred their relatives and neighbors - and sometimes even their own parents." 58 Women may also be ashamed, and may be actively shamed by others, for attempting to get acknowledgment and redress for their injuries and losses, sexual and otherwise, when "there is no comparison to the hardship of battle." 59 In other words, it is the suffering that is paradigmatically that of men in war - or men killed or disappeared in political activity - that deserves attention, and women may be intimidated and shamed for suggesting that their suffering deserves acknowledgment, much less redress. In this way women's own suffering "becomes invisible even to themselves." 60

As mentioned earlier, the "feminized" position of the victim of sexual violence means that male victims will also bear heavy burdens of shame when they are sexually victimized, although the longer-term social and psychological consequences of being a male victim of sexual violence in conflict, as well as the incidence of sexual violence between men, are unclear in comparison to what we know about women. If the practice of attending to sexual violence toward women in conflict is recent, the practice of recording and investigating sexual violations of men is not clearly established, although there are some pioneering efforts. ${ }^{61}$ Proposed reparations in Timor-Leste provide for boys and men who are victims of sexual violence. ${ }^{62}$

$5^{8}$ Thernstrom, 38; Sideris, $14^{8}$, describes abducted Mozambican women's feeling like "active participants."

59 Sheila Meintjes, Anu Pillay, and Meredeth Turshen, "There is No Aftermath for Women," in The Afternath, Meintjes et al., 14 .

${ }^{60}$ Guillerot, 147 . Chillingly, Goldblatt and Meintjes discuss the exposure of women to sexual abuse within their own underground and military organizations. They report from an interview with Theniiwe Mtintso, a senior member of the South African ANC's army: "She said the men knew that women would not want to talk about having been raped. One of her comrades said to her, 'You know, it's going to get to the point that I am going to rape you. And it's going to be very easy to rape you and I know that there is no way that you are going to stand in front of al these people and say I raped you." Goldblatt and Meintjes, "South African Women Demand the Truth," 50.

${ }^{61}$ See Zarkov; see also Sivakumaran.

62 Wandita, 263

\section{Women's Insecure Testimonial Positions}

Working in the former Yugoslavia, psychologist Ingrid Foeken says, "There was too much shame, and raped women were at risk of being driven out of their community if they were found out," stressing the hesitancy of women to discuss sexual violation even in a therapeutic context, much less to make a public admission or legal complaint. ${ }^{6}{ }_{3}$ According to Beth Goldblatt and Sheila Meintjes, "Women do not speak about rape out of shame, for fear of loss of status, because they do not want to relive the pain, and because they are often unwilling to subject themselves to cross-examination by the accused person's defense lawyer." 64 Accurate information, accessible processes, a public environment that validates the victim and blames the assailant, and guarantees of confidentiality and security are among the conditions that could increase women's willingness to report and to pursue legal and other redress for sexual violation. Human Rights Watch, for example, describes misunderstandings and lack of protection that have inhibited rape victims from coming forward in Rwanda, and Goldblatt and Meintjes describe women's belief in the South African context that to report sexual abuse to the TRC they had to testify publicly or have their violation revealed. ${ }^{65}$ Finally, women often have concrete reason to fear reprisal from men with whom they continue to live in close proximity and who may continue to enjoy social authority in the aftermath of conflict. This is especially true when the likelihood of criminal prosecution is negligible or when amnesty has been given, and it may also affect women's participation in nonjuridical processes like truth commissions or traditional practices like the Rwandan gacacas. ${ }^{66}$

Alongside the burdens of shame and fear women experience in the wake of violence, there is also the commonplace and continuing lack of standing, or uncertain standing, of women to speak publicly or to give testimony in many societies, and there may be additional burdens applied to women in customary and legal practices with regard to sexual assault. Silencing,

63 Ingrid Foeken, "Confusing Realities and Lessons Learned in Wartime: Supporting Women's Projects in the Former Yugoslavia," in Assault on the Soull, Sharratt and Kaschak, 93.

$6_{4}$ Goldblatt and Meintjes, 53 . See also Human Rights Watch, "Struggling to Survive," $1-58$, on low rates of reporting by women of sexual violence.

65 Human Rights Watch "Struggling to Survive" and Goldblatt and Meinties. See also Debra L De Laet, "Gender fustice: A Gendered Assessment of Truth-Telling Mechanisms," in Telling the Truths: Truth Telling and Peace Building in Post-Conflict Societies, ed. Tristan Anne Borer (Notre Dame: University of Notre Dame Press, 2006).

66 Meredeth Turshen "Women's War Stories," in What Women Do In Wartime, Turshen and Twagiramariya, 8. See also Human Rights Watch, "Struggling to Survive," and Rombouts, $231-232$. 
through structural and legal means, as well as direct personal pressure, is an integral part of most oppressive social arrangements, especially where they enable those with superior power to commit violence, and this is definitely true in the subordination of women in many social settings. Truth-telling requires not only the will to do so (raising questions of physical and social security), but also the means, opportunity, and standing to do so. Women have in many societies been assigned "speechless standings" that forbid or disqualify by law or custom their testimony relative to certain matters, that require the permission of men to speak, or that impede women's access to the needed public, legal, and institutional avenues of expression. These are impediments to women being able to enunciate their experiences and report their injuries, and so help render women's injuries invisible. ${ }^{67}$ In conflicts involving indigenous communities, vulnerable ethnic groups, or national minorities, women and men who are victims of conflict may be additionally marginalized by the languages they speak, which are usually not the languages of legal and political institutions, a concrete problem of access to reparations mechanisms. ${ }^{68}$

Indeed, when we consider the formidable and continuing barriers - personal, familial, customary, legal, and institutional - to women's speaking publicly and with authority, it helps explain why women who speak about violence tend to do so about the violence inflicted on others, especially others in their families, putting themselves in the service of others' losses and suffering, fearing or ashamed to speak their own. At the same time men are entirely aware of the barriers to women's speaking publicly and appreciate how little recognition and validation women who do manage to speak out are likely to receive. When it comes to sexual violations of women, anticipated impunity and even anticipated invisibility are fully reasonable assumptions for male perpetrators in many social climates, even if they end up on the losing political side in a post-conflict era. In this respect, the surge in attention to sexual violence in the past decade is a mixed blessing in the absence of either effective prosecution or reliable rights to reparation. Lyn Lusi, founder of a clinic for sexual violence victims in the Democratic Republic of Congo, laments, "all that publicity is saying, there's impunity, there's impunity. There's nothing to frighten people... now they know they can do it without paying the consequences. $" 59$

${ }_{7}$ Walker, "Truth and Voice in Women's Rights."

${ }^{68}$ Paz y Paz Bailey, 116-117, reports on multiple barriers for rural Mayan women in Guatemala.

${ }^{69}$ Integrated Regional Information Networks (IRIN) Web Special on violence against women and girls during and after conflict, September 14, 2004, http://www.irinnews.org/webspecials/ gbv/gbv-webspecial.pdf, accessed February 26, 2009 .

\section{RELEVANT CATEGORIES OF VIOLENCE AND HARM TO WOMEN}

It must always be emphasized in considering violence against women in conflict and repression that women in many respects will suffer what men suffer, both as combatants and as civilians. Although war continues to be seen commonly as a male domain, wars of liberation and civil conflicts in Africa and Central America, for example, have involved substantial numbers of women soldiers. Where women fight or engage in combat-support functions, women can be killed, wounded, tortured, coerced into performing atrocities, or detained and punished inhumanely. All forms of acknowledgment, reward, and redress that apply to male combatants and support personnel should routinely go to women on the same bases and to the same extent. A failure of demobilization, peace agreements, or reparation programs to treat women equitably is itself a matter for redress. The categories of violence and harm mentioned below, however, can be visited on women when they are in combatant roles or when they are civilians, and when they are activists or when they are not actively involved in political struggle or resistance. The dualities of combatant/noncombatant and activist/nonactivist should not be intentionally or inadvertently overlaid with a gender division between male and female. In whatever roles or status women inhabit in a context of conflict or repression, they might suffer or be victimized in precisely the same ways that men are, but also in gendered ways reflected in the categories below.

Contemporary warfare undeniably entails huge civilian casualties. ${ }^{70}$ The intensity of wars waged within or across borders, close to the ground, primarily with light weaponry, and without sharp boundaries demarcating zones of combat, expose whole populations in any area of conflict to death, injury, and violation and result in large-scale displacement of people from their homes and states. ${ }^{71}$ Insofar as women often make up half or a large majority of

$7^{\circ}$ Cockburn, "The Continuum of Violence," gives a figure of 9o\% for civilian casualties in contemporary war. Giles and Hyndman, "Introduction," 5 and 35 , give a figure of $60 \%$ to $80 \%$. I thank Vanessa Farr for pointing out how dubious are comparisons between contemporary wars and earlier ones, given that the sack of cities, the (sometimes genocidal) massacre of populations, and the enslavement of men, women, and children in war seems coextensive with the recorded history of warfare.

${ }^{71}$ On the consequences for civilians of small and light arms in West African conflict, see Corinne Dufka, "Combating War Crimes in Africa," Testimony Before the US House International Relations Committee, Africa Subcommittee, June 25, 2004, http://www.campboiro. org/bibliotheque/hrw/combating_war_crimes.html, accessed February 26, 2009. There is a growing literature on the gendered dimensions of small arms. See Vanessa Farr et al., "Gender Perspectives on Small Arms and Light Weapons: Regional and International Concerns," Bonn International Center for Conversion, Brief 24, http://www.bicc.de/index. php/publications/briefs/brief-24, accessed February 26, 2009. 
the populations in most areas, one would expect civilian death, injury, and displacement to afflict women in large numbers, and in some cases (although not necessarily all) women will be disproportionately affected, although sex ratios in refugee or other displaced populations differ in different political situations. ${ }^{72}$ Conflict situations that affect particularly large or disproportionate numbers of women need to be tracked and assessed for their impacts - losses, harms, and the burdens of increased vulnerability of several types - the nature and severity of which are likely to be shaped by gender.

The idea of "gender-specific," "gender-linked," or "gender-based" violence naturally appears in discussions of what happens to women in conflict. The terminology of "gender-specific" violation in connection with female victims can carry the misleading implication that some acts of violence, including sexual violence, happen only to women. The idea that violence is "gender-linked" or "gender-based" is usefully broad, but for that reason fairly undiscriminating as to why and how being female or male is a risk-factor for, or an explanation of, certain kinds of violent victimization or the damage that results from certain kinds of violence and harm. The category of gender-based violence applied to women covers every form of violence for which women might be targeted based on their physical vulnerabilities or distinct biology; their economic, sexual, and symbolic values in their own eyes and in the eyes of men and their communities; or their central roles in producing and sustaining children, social structure, and social capital. Beginning from an interest in what (perhaps distinctively) happens to women, I suggest that four broad categories are useful to begin to sort through the different ways that women's physical sexual, social, economic, political, communal, spiritual, and symbolic positions figure in the violence and harms that befall them in conflict. These categories create a coarse grid but provide an initial basis for understanding different but interacting links between gender, violence, and harm in the case of women.

$7^{2}$ Different figures concerning refugees and internally displaced persons reflect different demographic and political realities. Meintjes reports the $80 \%$ figure in Sheila Meintjes, "War and Post-War Shifts in Gender Relations," The Aftermath, Meintjes et al., 67. Turshen observes that since women and children account for over $72 \%$ of most African populations, "the demographic profile of refugees is little different from that of civilians" in Turshen, "Woneen's War Stories" 15 . Amuesty htentiont couts wom and gits as as a Tool of War: A Fact Sheet," www.amnestyusa.org/women/violence/rapeinwartime.html, accessed February 26 , 2009. For exhaustive data disaggregated in multiple ways, see United Nations High Commission on Refugees, The State of the World's Refugees 2006: Human Displacement in the New Millenium, http://www.unhcr.org/publ/PUBL/4444afc50.pdf, accessed February 26 , 2009 .

\section{Gender-Normative Violence and Harm}

If masculinity is defined through sexual possession, use, and domination of women, then acts of violence to achieve this are inflicted on women because they are women. If dominance among men and their masculinities is embodied in men's ability to control, exploit, and sexually appropriate "other men's women," then women are targeted precisely because they are women by groups of men who aim to defeat, dishonor, and shame other men. If women are seen as representations of cultural, ethnic, and national identity, as well as repositories of cultural authenticity, communal order, and righteous purity, then women's bodily integrity and purity are attacked and destroyed because they are women and doing so demoralizes and destroys communities and proves their men are inadequate to protect them. If women are both materially and symbolically the guardians of the social and emotional tissue of relations that knit a community, then soiling and shaming women makes them unsuitable or disqualifies them as women for social life and its female functions and offices.

By all reports, sexual violence in current struggles is endemic, and the testimonies of those who survive and are brave enough to tell their tales are heart rending and stomach turning. Amnesty International's 2005 Report describes continuing widespread rape and sexual mutilation and humiliation in interstate and intrastate conflicts, with child rape alarmingly common in some areas. Sexual violence is not only the most evident instance of violence that is gender based, but it is a prism that makes visible multiple aspects of female gender that are in play in many societies when women are targets of violence. The key in getting these offenses in proper focus is relentlessly to denormalize and defamiliarize violence against women in every instance, to resist the inertial movement toward seeing the violation and terrorization of women as the way the world is, and toward seeing women's bodies as sexual and reproductive utilities in communities and relationships controlled by men. Additionally, it is important to recognize differences among women with respect to their exposure, their reactions, and the likelihood of their securing attention to gender-normative violence. What is gender normative within a society may differ between social groups; some women's honor and purity may be more highly valued and may be taken more seriously as a representation of national identity than that of others from less-powerful social groups; women of different social groups may bear different burdens of silencing and shame in the wake of violation and abuse. These factors might account for more attention to the injuries of some women, different perceptions of the seriousness of those injuries, or varying needs for confidentiality and prospects of public solidarity among different groups of women. 


\section{Sex-, Reproductive-, and Care-Specific Violence}

Violence toward women, it is abundantly clear, goes very often to their sexuality and reproductive capacity, to their sexual or reproductive parts, and to their role as caregivers responsible for the young and dependent. Though sexual control of women by men is gender normative in many societies, and some forms of specifically sexual violence may be accepted, violent abuse of women that takes a sexual form deserves its own category, for it seems frequently to spill beyond any familiar normative boundary and is often shocking for its gratuitous cruelty and for its potential to mar lives socially, psychologically, and physically. As noted earlier, there are strategic, symbolic, instrumental, and also sadistic aspects to this extremely commonplace form of violence against women. The kind of mistreatment aimed at or exploiting sexuality or gender occurs not only through rape, physical abuse, or mutilation, although the scope and intensity of these forms of violence in conflict seems to be increasing. It occurs also through using women's familial and care-giving roles and responsibilities to terrorize, torture, punish, or degrade women in their own eyes and in the eyes of their families and communities.

Conway Henderson explores through comparative research "an additional pattern of mistreatment" women suffer under political repression. ${ }^{73}$ Women in detention, for example, suffer many of the same mistreatments and violations as do men, including beatings, torture, and attacks on psychological integrity. Men too are sometimes sexually abused and humiliated. Even so, there are distinctive and additional forms of cruelty and humiliation that are directed to women's real and perceived vulnerabilities. The gendered specificity of the torture of women in detention, by no means limited to rape, is increasingly documented. Women's sexuality, motherhood, sense of propriety and dignity, and profound sense of obligation for the welfare of their children are levers worked by torturers to inflict unbearable psychological torment on women. ${ }^{74}$ In addition, there are forms of humiliation that target women's biologies and social vulnerabilities to disorient women and damage self-respect; these include forced or public nakedness and denials of sanitary provisions for menstruation in detention, rendering women not only uncomfortable but helplessly dirty and ashamed. Latifa Jbabdi reports that women held as political prisoners in Morocco were addressed by men's names and

73 Henderson, "The Political Repression of Women."

${ }^{74}$ Goldblatt and Meintjes, "South African Women Demand the Truth," 37-45, report testimonies of female torture victims in South Africa. placed in male prisons, not only scorning their womanhood but exposing them to sexual violence as a punishment. ${ }^{75}$ Women of differing social positions may be more or less able to join together directly to confront the stigma of sexual violence. Some are likely to be more in need of, or more able to take advantage of, support services or confidentiality. The gender norms and scripts of local cultures will inflect the experience, the expression, and the consequences of surviving these forms of violence. Finally, there is the immense problem of pregnancies resulting from rape and sexual enslavement, a fate only women can suffer and of which the effects are likely to be life-altering.

\section{Gender-Skewed Violence and Harm}

Losses, harms, and violent injuries need not happen to women directly because of gender-normative assumptions or because women are targeted in ways specific to their sexuality, reproductive capacity, or care responsibilities. Yet in particular situations those who bear the brunt of a certain kind of violence or of certain effects of conflict may turn out to be largely and perhaps disproportionately (in virtue of the demographic of the peacetime population) female. Destruction of home sites, forced displacement, and removal to formal or informal refugee areas seem to be gender-skewed impacts of conflict in many cases. Where internal or external displacement does disproportionately afflict women and children, women may sustain the brunt of the distress, harm, social uprooting, and economic losses these dislocations entail. Displacement due to conflict or persecution constitutes a grave form of harm to those displaced, even if it removes them from the scene of formal conflict. They are no less victims of conflict for being raped, starved, sickened, or stripped of their possessions, documentation, or citizenship once they have become refugees or internally displaced persons.

Contemporary warfare - with either massive bombardment and destruction of infrastructure, or protracted ground war, provisioned by looting, aimed at demoralizing, displacing, or destroying populations - tends to wreak havoc on women, elderly persons, and children in massive numbers. Women who lose their spouses and other male family members to conflict, and who see their children conscripted, abducted, or killed, or who must abandon their homes, suffer what human beings experience as one of the greatest and most enduring

75 Latifa Jbabdi, oral presentation on Morocco, International Center For Transitional Justice Conference on "Gender and Reparations: Opportunities for Transitional Democracies?" July 7-8, 2005, New York. 
losses, that of home and family. This happens to women in conflict and because of conflict, so it is indeed a harm of conflict and matter for redress. The prevalence of severe losses and displacements of women noncombatants illustrates the importance of acknowledging grave harms of conflict that are not limited to acts of violence intentionally committed directly on individuals. The design of reparation must consider life-altering losses that result from violence to family and community members, destruction of material and social resources women need to sustain themselves and their dependents, and exposure to illness and violence that befall women under rough or dangerous conditions of displacement or loss of male social protection and status. If these losses are seen as merely collateral, regrettable but not obligatory to compensate, women are likely to be disproportionately and sometimes disastrously disadvantaged in many post-conflict situations. Differences among the situations of urban and rural women, of married and unmarried women, of women with dependent children and elders, and of women who belong to already poor, culturally vulnerable, or indigenous populations are central to accurately reckoning material losses and meaningful forms of material support and compensation.

\section{Gender-Multiplied Violence and Harm}

Some forms of violent harm or loss precipitate further losses that enlarge the impact of, and may in the end be worse or less manageable than, the original violation or loss itself. When the factors are social or biological ones that cause women to suffer more than their male counterparts would from particular acts of violence, or that render women vulnerable to additional harms as a result of acts of violence or the consequences of such acts, I refer to the harm as "gender multiplied" for women. Multipliers are factors that predictably play roles in causing additional losses or additional exposure to violence. The additional damage may or may not be part of what is intended in the violent act. The absence of intention to cause certain further harms or additional suffering, however, though relevant in a juridical context to assessing the nature of a crime, should not impede recognition of the need for repair of additional harms women suffer as consequences or sequels of violence.

Being the victim of some forms of violence has significant social consequences for females in many societies. The obvious case is sexual violation. It is a fairly recent development in North American and European societies that women are not routinely blamed and despised for having been raped (or at any rate the social presumption has now been shifted at least in formal legal and institutional contexts). In many societies, the onus on the victim of sexual assault remains pervasive, severe, and relatively certain to follow. The victim of sexual violence may be regarded as disgracing family honor, being unclean or contaminated, being a seductress of bad character, or being unmarriageable. Women who are sexually violated, impregnated by rape by enemies, sexually tortured and raped in detention, or kidnapped into sexual and domestic enslavement often are subjected to these socially blighting effects. The original violation is extended, ramified, and augmented in multiple ways that significantly alter the women's physical safety and well-being, social reintegration and status, economic survival, and eligibility for marriage. In addition to social and symbolic multipliers of harm, there is the reality that sexual and sexually directed physical abuse (violation or mutilation of genitals or reproductive parts) of women can produce irreversible and chronic physical disabilities, pain, sterility, or dysfunction. A Human Rights Watch report on Darfur mentions internal bleeding, fistulas, incontinence, and sexually transmitted diseases including HIV/AIDS as results of rape and other sexual abuse. ${ }^{76}$ Stephen Lewis, UN ambassador to Africa for AIDS, warned at the 2006 international AIDS meeting that "the violence and the virus go together." 77 Unwanted pregnancies, with significant implications for physical health and social reintegration, are among the consequences.

It is not only victims of sexual violence whose injuries and losses are multiplied. Problems of social stigma and exclusion are not reserved only for women who are noncombatant victims. They can befall women who have been combatants, or who have been placed out of supervision of family or clan or out of traditional roles in ways that are taken to impugn their purity or respectability. Codou Bop describes the demobilization of as many as 12,000 Eritrean women combatants whose military service and involvement in killing left many divorced, "unclean," and unmarriageable, for some a road to urban prostitution. $7^{8}$ Furthermore, women who lose husbands and children may suffer dramatic losses in economic and social status, and affronts to personal dignity. Meredeth Turshen notes, "War creates widows. In Rwanda it turned independent women into charity cases; women who before the war had access

${ }^{76}$ Human Rights Watch, "Sexual Violence and its Consequences among Displaced Persons in Darfur and Chad," Human Rights Watch Briefing Paper, April 12, 2005, 12. See also Rombouts, 208, and King, 251 and 263. A poignant and vivid first-person account of sexual slavery and its physical and emotional consequences is Maria Rosa Henson, Comfort Woman: A Filipina's physical and emotional consequences is Maria Rosa Henson, Comfort Woman: A Filipina's
Story of Prostitution and Slavery Under the Japanese Military (Lanham, MD: Rowman and Littlefield, 1999). Mrs. Henson was the first sexually enslaved woman to accept a reparation payment from a privately organized fund.

77 Lawrence K. Altman, "U.N. Official Assails South Africa on Its Response to AIDS," The New York Times, August 19, zoo6.

${ }^{8}$ Bop, "Women in Conflicts," 29-30. 
to land through their husbands are now destitute and dependent on relatives or social workers. War widows who were raped are stigmatized and find it hard to remarry; widowed rape victims with children are ostracized."79 Goldblatt and Meintjes report on the South African context, "When women lose their husbands they become doubly repressed by their own community; they become women without standing, almost illegitimate in the present context of South Africa's cultural reality. The son becomes the woman's husband, even if that woman was a very high-powered political activist." ${ }^{10}$

Displacement may also result in loss of access to land and agricultural livelihoods, as well as to trade, either in the place of exile or upon return. The poverty that results may be what stymies possibilities of a stable future that were not precluded by the fact of displacement alone. Women are almost invariably responsible for dependent children's sustenance and welfare, irrespective of external changes in women's abilities to secure food, clothing, and shelter, and to provide for education or other significant needs that may determine their children's future, and by consequence their own future welfare. The pathetic situation of women and children raped and killed because they have to go beyond the protected perimeter of camps to collect firewood for sale or fuel in Darfur has been documented, as have cases of Sudanese women and girls imprisoned for going outside refugee areas in Chad, only to be raped by Chadian inmates while in detention. ${ }^{81}$ The UN Security Council has recently condemned sexual abuse and pedophilia among its peacekeeping troops. It now appears that being female (or a child) and part of a civilian population in need of international protection is an additional risk factor for sexual abuse in some areas. ${ }^{82}$ Chain reactions of loss, social incapacitation, displacement, poverty, and sexual victimization should be seen as central to

79 Turshen, "Women's War Stories," 16

${ }^{8 \circ}$ Goldblatt and Meintjes, "South African Women Demand the Truth," 35.

${ }^{83}$ Human Rights Watch, "Sexual Violence and its Consequences among Displaced Persons in Darfur and Chad" 8

82 "U.N. Council Condemns Sex Abuse by Its Troops," The New York Times, June 1, 2005. Save the Children UK reports in 2006 that based on interview studies, Liberian girls as young as eight years old are being sexually exploited by UN peacekeepers, aid workers, camp officials, and teachers; in Sarah Lyall, "Aid Workers Are Said to Abuse Girls," The New York Times, May 9, 2006. Economic and social dislocation produced by conflict can press more women into prostitution or make them available to traffickers: reports on trafficking indicate that countrie with an influx of international peacekeeping and humanitarian workers attract greater numbers of trafficked women. See Dina Francesca Haynes, "Used, Abused, Arrested and Deported. Extending Immigration Benefits to Protect Victims of Trafficking and to Secure Prosecution of Traffickers," Human Rights Quarterly 26 (2004): 221-272. A United Nations policy statement is found in United Nations Cencral Assembly "AComprehensive Strategy to Eliminate Future Sexual Exploitation and Abuse in United Nations Peacekeeping Operations," March 24, 2005, A/59/710. reckoning violence, harm, and loss from the point of view of reparation and social reconstruction.

In addition, since rehabilitation is established in the international standards governing reparation, special attention should be paid to the social, physical, and psychological injuries sustained by:women, and care should be taken to find the most productive and culturally attuned interventions. There is no reason to assume, and good reason not to assume, that women's experience and assimilation of harms and losses, or their modes of adaptation and life reconstruction, will be entirely similar to men's. Nor can it be assumed that all women will have a single characteristic experience in a given conflict, or even when they are victims of similar violence in a given conflict. Women of different classes, ethnicities, castes, and religious groups, indigenous women, women who participate in oppositional political movements or are mobilized in combat, urban and rural women, married and unmarried women, women of different age groups and educational levels all need to be addressed as women, as individuals, and as members of groups with particular resources and vulnerabilities. They are likely to face very different challenges, to have access to different kinds of resources, and reasonably to expect very different social responses to their attempts to stabilize and mend their lives. In the case of women, we know that harms can be multiplied in many ways directly linked to gender, but also to gender in the context of race, class, ethnicity, political participation, rural life, or indigenous community.

Finally, there is a widely acknowledged post-conflict effect that afflicts both women who have otherwise suffered violence in or because of conflict as well as those who might have escaped this fate. Several reports affirm that "ordinary" violence against women escalates in post-conflict periods because of men's inability to find positive peacetime roles that restore a sense of masculinity, men's conception of reestablishing the status quo as entailing a return to "traditional" gender relations, or men's desires to reassert control over women who have developed economic and survival skills in wartime that challenge their traditional subordination or that put women in competitive positions with men domestically or occupationally. ${ }^{83}$ Women are themselves seen as material assets and may possess material assets that men want to control. In this way conflict itself seems to be a multiplier for women's exposure to "ordinary" violence in the aftermath. But women's antecedent material resources and

${ }^{83}$ Meintjes, Pillay, and Turshen, "There is No Aftermath for Women," 4; Sideris, 152; Anja Meulenbelt, "Sympathy for the Devil: Thinking About Victims and Perpetrators after Working in Serbia," in Assault on the Soul, Sharratt and Kaschak, 154-155; and Duggan and Abusharaf, "Reparation of Sexual Violence," 627 
social position, and their post-conflict access to local power and larger legal and political structures, are likely to matter profoundly to whether harms multiply. Interventions to neutralize or limit factors that multiply women's losses and suffering cannot be "one size fits all," and women's social power and communal organization or lack thereof may be a factor in containing multiplier effects or in the effectiveness of interventions.

Clearly, these four categories are by no means mutually exclusive in application to women: most sexual violence, for example, is gender normative, sex specific, gender skewed, and typically gender multiplied. Sexual mutilation of women is not necessarily gender normative but is sex specific or reproduction specific and may or may not be skewed or multiplied. The destitution women suffer as a result of destruction of physical and social infrastructure is gender skewed in many situations by women's gender-normative economic vulnerability in patriarchal orders, and it is likely to be gender multiplied in distinctive ways, as displacement is likely in some contexts to affect more women and to expose them to gender-normative and gender-multiplied consequences. These categories are a tool both to sort and to link the forms of harms and violence that happen to women "because they are women."

In cases of gender-normative and gender-multiplied violence, women may be reluctant to acknowledge their violation or not inclined to expect or to pursue any form of redress. Having suffered gender-normative and even sexually specific violence, women may be resigned to "what happens to women," or may perceive - sad to say, correctly - that others will view their mistreatment in that way. Where situations of loss are gender skewed, women may themselves perceive their dire situations as a kind of collateral damage, a "secondary" effect for which they in particular are not targeted and no one else in particular is responsible, or as a sort of ill fortune that should not be compared to those who have died or suffered terrible physical injuries. Where this is true, women may focus on the immediate needs of survival assistance and security, or on a longer-term goal of return or resettlement, without expectation of redress. We know that women often tend to focus, and are encouraged to focus, on the harms that befall others to whom they are connected and for whom they are responsible, even to the exclusion of reporting or seeking redress for the violation or loss they themselves have suffered. In addition, women's membership in particular social, economic, and geographical groups is likely to determine what is gender normative for them, what risks of violence and multiplier effects they in particular bear, whether they are likely to report violations, and what potential there is for solidarity among women to secure post-conflict political power and resources. In post-conflict contexts women may be competing for scarce resources and their loyalties may be with family, tribe, clan, or locality, and with the men with whom they share their daily lives and on whom they depend, rather than with other women. Reparations programs must aim at gender justice where women themselves may not see this as a priority. The proposed categories of violence and harm need to be attuned and adjusted to the experience, perceptions, needs, and deserts of particular victims in particular contexts, and these contexts need to be explored directly in every case.

In the interests of gender justice, however, we must also think about men, and about men and women both in comparison and in relationship to understand fully how the violence, harms, and losses of conflict and political repression are structured by gender. Although I have begun with the question "What happens to women?" the categorization I offer can respond to the guiding concern of sensitivity to gender in assessing harms for both women and men. If women suffer kinds of violence and ensuing harm in multiple senses "because they are women," then so do men suffer kinds of violence and ensuing harm "because they are men." The fact that men are usually disproportionately targeted for the gross human rights violations that tend to attract attention in reparations programs (murder, disappearance, kidnapping, illegal detention, and torture) shows that some forms of violence and harm are in many contexts gender skewed and attached to gender-normative masculine roles and activities, like military service and political leadership. The presumably grossly underreported category of sexual violence toward men, especially rape of men by men as well as sexual abuses and mutilation, follows a gender-normative pattern of insult: raped or sexually used men are feminized and "unmanned." Men, too, are targeted for harms and tortures that are directed at their sexual parts and functions. ${ }^{8}{ }^{8}$ So men experience sex- and reproduction-specific violence, as well as forms of abuse and torture that exploit men's parental and familial love and responsibility. Men are forced to stand by when their parents, spouses, relatives, and children are killed, beaten, raped, or tortured in front of them. Men are coerced or terrorized by threats to their families. Men suffer the trauma of seeing loved ones injured and suffer the shame of their incapacity to exercise culturally valued protective male roles. Men are also subject to grave psychic and physical costs and consequences of participation in combat, and in the atrocities and abuses they witness or commit under the pressures and expectations not only of political ideology and military discipline but of gender norms of manliness and male solidarity. Men, too, may face multiplier

${ }^{84}$ See Sivakumaran 
effects when they are victims of violence or loss, and the specific gendered trajectories of men's being disabled, traumatized, displaced, impoverished, or sexually violated require investigation alongside and in comparison to women.

Thus, the categorical framework I propose has potential for multiple and nuanced comparative analyses of the gendered nature and impacts of violence that attends to experiences of both women and men. Within this framework, we can engage in comparative investigation of overall gender-linked differences in the fates of men and women in a particular conflict. We can explore differences in gendered exposure to loss and violence among groups of women or among groups of men differently positioned within the same conflict situation. We might also track and compare overall gendered differences in what happens to men and women in different conflict situations. Or we might explore in depth the fine grain of gender-normative or gender-multiplied harms within or between conflicts. Finally, the same categories might be used or adapted to address the experiences of members of sexual minorities in conflict or under repression where gendered dynamics are apt to play out in distinct ways. These categories offer the potential for a fuller topography of gender and violence, but they are always guided by the question: What distinctive and possibly gendered forms of violence, harm, and suffering must be specifically investigated and addressed in programs designed to deliver effective reparation in the wake of armed conflict or political repression?

\section{CONCLUSION}

Can one actually say it's violence? ... It's not as serious as my husband being killed in jail. One would say, it's not like me having left my own country going to stay thirty years outside. So that's what I always say to myself, what is this violence? How can one express it to somebody who can actually feel sympathetic? What I'm telling you now is a story. I don't think it will be seen as violence. It's a story that this is how we lived in the past. And this was where it actually crippled me in my mind.

- Lydia Komape, a black women under South African apartheid, who had to falsify her Bantu identity (a crime), break up her family, and take up domestic labor away from her husband, who risked arrest to see her ${ }^{85}$

When you hear people like this woman, let's call her Natasha K., who testifies that she has lost 35 people in her family, and then the prosecutor asks her

\footnotetext{
${ }^{85}$ Quoted by Goldblatt and Meintjes, "South African Women Demand the Truth," 33
}

to look at photo after photo, and she says this was her husband, this was her uncle, and this was her father-in-law... . You listen to that kind of loss and it's just unbearable.

$$
\text { - Judge Gabrielle Kirk McDonald, former President of the ICTY. } 86
$$

People feel that once we have identified who killed who, we were just about finished. Only then can we address such questions as who raped who, who burned what, and then who stole the cows.

- Patricia Viseur-Sellers, Legal Officer on Gender Issues at the ICTY. ${ }^{87}$

They were so bitter at the state. Their houses were burned, they were raped, their husbands were killed, and their sons were abducted. They feel they lost a lot and must be paid, they must be compensated or the rebels must be arrested and brought to justice.

- A description of the situation of women in war-torn northern Uganda. ${ }^{88}$

The "multi-dimensional nature of their suffering" is a striking theme of investigations of violence toward women and losses experienced by women in conflict and under repression. ${ }^{89}$ Looking closely at patterns of violence directed at women and features of women's gendered roles and social expectations is urgent because these patterns have so long been ignored or naturalized as "what happens to women." Specific synergies of loss and suffering must be explored if women are to receive just reparation. In particular, sexual violence in conflict situations very often, perhaps typically, is one aspect of multifaceted episodes of violence and terror in which women are victims of violence to their physical persons, subjected to multiple losses and harms, made instruments of communal intimidation, and made witnesses to other atrocities. A legal advisor to the ICTY reports, "One has to remember that rape is generally not the only crime inflicted against that person on that day. Often in wartime you might have a victim or a witness who has been shot, has seen family members killed before their eyes, been detained, starved or tortured, in addition to the sexual violence inflicted on them." 90 The pattern of multiple and reciprocally magnifying assaults and horrors is common.

${ }^{86}$ Sara Sharratt, "Interview with Gabrielle Kirk McDonald, President of the International Criminal Tribunal for the Former Yúgoslavia," in Assault on the Soul, Sharratt and Kaschak, 26-27.

${ }_{87}$ Sara Sharratt, "Interview with Patricia Viseur-Sellers, Legal Office on Gender Issues," in Assault on the Soul, Sharratt and Kaschak, 66.

${ }^{88}$ Quoted by Meredeth Turshen, "Engendering Relations of State to Society in the Aftermath," in The Aftermath, Meintjes et al., 95.

89 Ashnie Padarath "Women and Violence in KwaZulu/Natal," in What Women Do in Wartime, Turshen and Twagiramariya, 68.

90 Sharratt, "Interview with Patricia Viseur-Sellers," 56. 
The many dimensions of harm to women and of women's suffering, and predictable links and devastating synergies among them, present difficult challenges. A central challenge is that recently won attention to sexual violence against women might be at the expense of a fuller and more nuanced understanding of women's losses, injuries, and sufferings. Unbending insistence on the full and accurate recognition and legal and political redress of sexual violence experienced by women is imperative. Even so, sexual offenses against women must not displace or overwhelm recognition of diverse and devastating harms of other types that women suffer, nor of the complex and often brutal causalities that link sexual violence to other kinds of loss, and other kinds of loss to exposure to sexual violence. Needed attention to sexual violence should not sexualize women as victims, duplicating rather than contesting the reduction of women to their sexual and reproductive being. Nor should sexual violence be associated entirely with women, further obscuring what remains largely shrouded in darkness: men are also victims of sexual violence in conflict and under repression. So it is doubly important to resist the conflation of sexual violence with violence against women. Harms suffered by men in conflict, and by men and women who are members of sexual minorities, are also diverse and may also be shaped, aimed, skewed, or multiplied by gender in any of the ways I have outlined. Focusing on women has opened the way for more sensitive, comprehensive, and comparative analysis of how gender shapes violence and harm for both men and women.

Other challenges emerge in identifying harms and their consequences fully and accurately for the purposes of considering and designing reparations. It will not suffice to identify harms to persons in conflict or under state repression only as those intentionally done to them by individual perpetrators, lest many gross harms to women and men fall back into the category of collateral damage. Even the attempt to recognize consequences of violence by incorporating individuals as "secondary" victims, as when a woman is left destitute by the murder of her husband or the abduction of her son, or when a man's wife is made pregnant by rape, for example, can fail to capture adequately the extent of loss and harm that women and men experience. The person whom a perpetrator intends to shoot or beat or rape is typically seen as the "primary" victim, whereas, for example, the wife who witnesses her husband's murder, the father who watches his wife and daughter raped and mutilated, the family that loses the male head of household on whom its economic survival depends, or the spouse who must assume both primary economic and daily care-giving responsibilities for a disabled partner are talked about as "secondary" victims where they are talked about at all. Yet these individuals are primary victims of terror, intimidation, and humiliation often intended to silence them, render them complicit or destitute, or drive them from their property and land; the forms of intimidation and humiliation chosen may follow gendered lines. Even when people are not or not only the direct victims of physical violence, they are the direct victims of intentional acts of terror, intimidation, and coercion that produce grave and life-altering losses that may be further compounded or aggravated in gendered ways..$^{91}$ Finally, even when ensuing losses are unintended, and even unforeseen, the losses are no less a product of the violence, and no less devastating for that reason. The typology of victimization remains an imperfect tool in capturing the nature and dimensions of real harm (unintended and intended) that women and men routinely suffer because of armed conflict or political repression..$^{2}$

The 2006 resolution on reparations of the United Nations General Assembly declares that "adequate, effective and prompt reparation is intended to promote justice by redressing gross violations of international human rights law or serious violations of international humanitarian law."93 Ruth Rubio-Marín adds that helping victims and their families, asserting the commitment to a system of rights, and recreating the conditions of civic trust for victims and others must be conceived together when thinking about reparation. ${ }^{94}$ I hope to have shown that appreciating the consequences of violations, grasping their precise and mutually ramifying nature, and creating the ground of trust through adequate acknowledgment of all victims requires close attention to the realities of violence in conflict and, at long last, to its gendered effects

91 Goldblatt and Meintjes say of South Africa's TRC including relatives and dependents as secondary victims, "It is important to see these women as primary not secondary victims, because they themselves have suffered directly," in Goldblatt and Meinties, "South African Women Demand the Truth" 34 Tristan Anne Borer "A Taxonomy of Victims and Perpetrators: Human Rights and Reconciliation in South Africa," Human Rights Quarterly 25 (2003): 1088-1116, examines the process whereby South Africa's TRC created official victims and perpetrators, and the possibility of sorting "direct victims," "victims once removed," "victims by proxy," and "secondary victims" (1115-1116).

$9^{2}$ The issue of framing of violation and harm is a central challenge. See Diane Orentlicher, "Promotion and Protection of Human Rights: Impunity: Report of the Independent Expert to Update the Set of Principles to Combat Impunity," E/CN.4/2005/102, 17, where the ideal of "completeness" of reparations is related to "the breadth of the categories of crimes for which the program provides redress." Pablo de Greiff argues for a political, rather than a juridical, perspective for reparations, in Pablo de Greiff, "Justice and Reparations," in The Handbook of Reparations. A political perspective might extend as well to the conceptualization of harms and less dominated by the legal emphasis on individual perpetators' intentions (often a defining element of crime) and more attuned to the experience of loss and violations of individuals and communities.

93 United Nations, "Basic Principles and Guidelines on the Right to a Remedy and Reparation for Victims of Gross Violations of International Human Rights Law and Serious Violations of International Humanitarian Law," March 21, 2008, A/RES/60/147.

94 Ruth Rubio-Marín, Chapter 2 of this volume. 
on women and men. It also demands observation and analysis of how gender creates differences between the experiences of men and women as victims, and how differences among women and among men mean differences in the impacts as well as the injuries they suffer. 95

95 I wish to thank Ruth Rubio-Marín for insightful editorial direction. Country studies commissioned for the International Center for Transitional Justice project on gender and reparations were published in Rubio-Marin's What Happened to the Women? I have benefited greatly from them and from discussion with the authors. Several meetings among authors of the country studies and contributors to the present volume shaped and enhanced this chapter in countless ways. Special thanks to Pablo de Greiff, Director of the Research Unit at the ICT), and to the ICT) staff. 